\title{
Two Dimensional Magnetic Coordination Polymers Formed by Lanthanoids and Chlorocyananilato ${ }^{\dagger}$
}

\author{
Samia Benmansour*, Antonio Hernández-Paredes and Carlos J. Gómez-García *(D) \\ Instituto de Ciencia Molecular (ICMol), Departamento de Química Inorgánica, Universidad de Valencia, \\ C/Catedrático José Beltrán 2, 46980 Paterna, Spain; anherpa@alumni.uv.es \\ * Correspondence: sam.ben@uv.es (S.B.); carlos.gomez@uv.es (C.J.G.-G.); \\ Tel.: +34-963-544-423 (S.B. \& C.J.G.-G.); Fax: +34-963-543-273 (S.B. \& C.J.G.-G.) \\ + In memory of late Professor Samiran Mitra. A good researcher, a better friend and an excellent person.
}

Received: 8 November 2018; Accepted: 6 December 2018; Published: 12 December 2018

\begin{abstract}
Here we show the important role played by the size of the lanthanoid and the solvent used in the final structures of several two-dimensional magnetic coordination polymers with the ligand chlorocyananilato, $\left(\mathrm{C}_{6} \mathrm{O}_{4}(\mathrm{CN}) \mathrm{Cl}\right)^{2-}$. With this aim we have prepared five compounds: $\left[\mathrm{Nd}_{2}\left(\mathrm{C}_{6} \mathrm{O}_{4}(\mathrm{CN}) \mathrm{Cl}\right)_{3}(\mathrm{DMF})_{6}\right](\mathbf{1})\left(\mathrm{DMF}=\right.$ dimethylformamide), $\left[\mathrm{Dy}_{2}\left(\mathrm{C}_{6} \mathrm{O}_{4}(\mathrm{CN}) \mathrm{Cl}\right)_{3}(\mathrm{DMF})_{6}\right] \cdot 4 \mathrm{H}_{2} \mathrm{O}(\mathbf{2})$, $\left[\mathrm{Ho}_{2}\left(\mathrm{C}_{6} \mathrm{O}_{4}(\mathrm{CN}) \mathrm{Cl}\right)_{3}(\mathrm{DMF})_{6}\right] \cdot 2 \mathrm{H}_{2} \mathrm{O}(3)$, and $\left[\mathrm{Ln}_{2}\left(\mathrm{C}_{6} \mathrm{O}_{4}(\mathrm{CN}) \mathrm{Cl}\right)_{3}(\mathrm{DMSO})_{6}\right]$ with $\mathrm{Ln}=\mathrm{Ce}(4)$ and $\mathrm{Nd}$ (5) (DMSO = dimethylsulfoxide). These compounds are formed by two dimensional networks with a (6,3)-topology but, depending on the size of the lanthanoid and on the solvent used, show important structural differences, including the size, shape, distortion and content of the cavities as well as the flatness of the layers. The comparison of compounds 1-3 and 4-5 shows the role played by the size of the lanthanoid while keeping constant the solvent, whereas, the comparison of compounds $\mathbf{1}$ and $\mathbf{5}$ shows the role of the solvent (DMF vs. DMSO) while keeping constant the lanthanoid. The magnetic properties of all of them show the absence of noticeable magnetic interactions, in agreement with previous results that can be explained by the internal character of the $4 \mathrm{f}$ electron and the weak magnetic coupling mediated by these anilato-based ligands.
\end{abstract}

Keywords: magnetic coordination polymers; lanthanoids; anilato-based compounds; chlorocyananilato; honeycomb layers; magnetic properties

\section{Introduction}

The synthesis of porous crystalline coordination polymers also known as metal organic frameworks (MOFs) presenting different cavities shapes and sizes is a hot topic in Coordination Chemistry nowadays [1,2]. The possibility to tune and modulate the shape and size of the cavities is a very important aspect in order to synthetize MOFs with tailored properties for applications in catalysis [3,4], gas storage and separation [5,6], energy storage $[7,8]$, water adsorption [9], biomedicine [10,11], sensors [12,13], or a combination of several properties in the same MOF [14].

These MOFs are mainly constructed with transition metal atoms (including group 12) and complexes of these metal ions that are connected through different organic ligands acting as linkers. Although less used, lanthanides can also be used to prepare MOFs with interesting properties as luminescence in order to prepare optical-based sensors of gases, contaminants and different chemical species [15-17].

Although there are hundreds of organic ligands that can be used as linkers, the most popular ones are polycarboxylic acids (including aromatic) [14,18-21], and azolates [22,23] thanks to their capacity to coordinate many transition metal atoms (and lanthanoids) with diverse coordination modes. Aromatic quinones as the 2,5-dihydroxy-1,4-benzoquinone dianion $\left(\mathrm{C}_{6} \mathrm{O}_{4} \mathrm{H}_{2}\right)^{2-}=$ dhbq and the 3,6-disubstituted 
dianions $\left(\mathrm{C}_{6} \mathrm{O}_{4} \mathrm{X}_{2}\right)^{2-}$ (anilato-type ligands) with $\mathrm{X}=\mathrm{CN} / \mathrm{Cl}, \mathrm{NO}_{2}, \mathrm{Br}, \mathrm{Cl}, \mathrm{CN}, \ldots$ (Scheme 1) have also been used to prepare MOFs with interesting magnetic properties [24,25]. One of the interests of these anilato derivatives is their topological resemblance with the extensively studied oxalato ligand (Scheme 1). Thus, anilato ligands form tris-quelate chiral monomers of the type $\left[\mathrm{M}\left(\mathrm{C}_{6} \mathrm{O}_{4} \mathrm{X}_{2}\right)_{3}\right]^{3-}[26,27]$, that resemble the well-known $\left[\mathrm{M}\left(\mathrm{C}_{2} \mathrm{O}_{4}\right)_{3}\right]^{3-}$ chiral complexes. Furthermore, anilato ligands also form extended 1D, 2D and 3D lattices with the same topology that oxalate [24,28-33]. Albeit, the anilato ligands present some interesting properties and advantages when compared with oxalato: (i) they are much larger and accordingly, their compounds usually present much larger cavities and channels (in fact, most structures with oxalato are not considered MOFs since they are not porous, in contrast to the equivalent anilato-based compounds) [28,34]. (ii) A second advantage is the possibility to modulate the electron density in the anilato ring by simply changing the $X$ group (Scheme 1 ). This change in $X$ leads to changes in the cavity sizes (since $X$ points to the centre of the cavity) and, most importantly, in the ordering temperatures of magnetic $\mathrm{MOFs}$ as in the series of anilato-based magnets $\left[\left(\mathrm{H}_{3} \mathrm{O}\right)(\mathrm{phz})_{3}\right]\left[\mathrm{MnCr}\left(\mathrm{C}_{6} \mathrm{O}_{4} \mathrm{X}_{2}\right)_{3}\right] \cdot \mathrm{G}\left(\mathrm{phz}=\right.$ phenazine; $\mathrm{X}=\mathrm{H}, \mathrm{Cl}, \mathrm{Br}$ and $\mathrm{I}, \mathrm{G}=\mathrm{H}_{2} \mathrm{O}$ or acetone) [30].

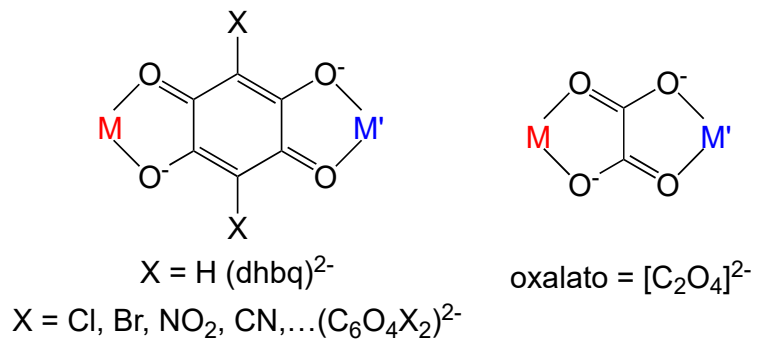

Scheme 1. (left) bis-bidentate coordination mode of the anilato-type ligands and of the oxalato ligand (right).

Besides transition metal ions, lanthanoids have also been used to prepare anilato-based neutral lattices formulated as $\left[\mathrm{Ln}_{2}\left(\mathrm{C}_{6} \mathrm{O}_{4} \mathrm{X}_{2}\right)_{3}(\mathrm{G})_{\mathrm{m}}\right] \cdot \mathrm{nG}$ whose structure depends on the size of the $\mathrm{Ln}(\mathrm{III})$ ion, the $\mathrm{X}$ group and the solvent used $(\mathrm{G})$.

The ligand $\mathrm{C}_{6} \mathrm{O}_{4} \mathrm{H}_{2}{ }^{2-}=\mathrm{dhbq}^{2-}$ with $\mathrm{G}=\mathrm{H}_{2} \mathrm{O}$ was used by Robson et al. [28,35] and later by some of us [36] to prepare the complete series of isostructural compounds formulated as [ $\left.\mathrm{Ln}_{2}\left(\mathrm{C}_{6} \mathrm{O}_{4} \mathrm{H}_{2}\right)_{3}\left(\mathrm{H}_{2} \mathrm{O}\right)_{6}\right] \cdot 18 \mathrm{H}_{2} \mathrm{O}$. In this series all the $\mathrm{Ln}(\mathrm{III})$ present the same structure: a $(6,3)-2 \mathrm{D}$ honeycomb lattice formed by regular non planar hexagons with the $\mathrm{Ln}(\mathrm{III})$ ions nona-coordinated with a tri-capped trigonal prismatic geometry.

For the ligand $\mathrm{C}_{6} \mathrm{O}_{4} \mathrm{Cl}_{2}{ }^{2-}=$ chloranilato and $\mathrm{G}=\mathrm{H}_{2} \mathrm{O}$, the change of the $\mathrm{Ln}(\mathrm{III})$ size leads to four different crystal phases, all based in the (6,3)-2D honeycomb lattice with formula $\left[\mathrm{Ln}_{2}\left(\mathrm{C}_{6} \mathrm{O}_{4} \mathrm{Cl}_{2}\right)_{3}\left(\mathrm{H}_{2} \mathrm{O}\right)_{6}\right] \cdot \mathrm{nH}_{2} \mathrm{O}$. These four phases (I-IV) only differ in the disposition of the coordinated water molecules around the $\operatorname{Ln}(\mathrm{III})$ ions, due to the change in the $\operatorname{Ln}(\mathrm{III})$ size. This change in the coordination environment results in important changes in the number of crystallization water molecules located in the cavities: $\mathrm{n}=14$, for the larger $\mathrm{Ln}$ (III) ions (La, Ce, Pr and Nd) in phase I, $\mathrm{n}=12$ for the intermediate $\operatorname{Ln}(\mathrm{III})(\mathrm{Sm}, \mathrm{Eu}, \mathrm{Gd}, \mathrm{Tb}, \mathrm{Dy}$ and Ho) in phase II, $\mathrm{n}=10$ for $\mathrm{Ln}=\mathrm{Er}(\mathrm{III})$ in phase III and finally, $\mathrm{n}=8$ for the smallest lanthanoids (Tm and $\mathrm{Yb}$ ) in phase IV [28,35,36].

With the ligand $\mathrm{C}_{6} \mathrm{O}_{4} \mathrm{Br}_{2}{ }^{2-}=$ bromanilato and $\mathrm{G}=\mathrm{H}_{2} \mathrm{O}$, we have obtained two different crystallographic phases (I and II), also depending on the size of the $\operatorname{Ln}(\mathrm{III})$ ion. These phases, formulated as $\left[\mathrm{Ln}_{2}\left(\mathrm{C}_{6} \mathrm{O}_{4} \mathrm{Br}_{2}\right)_{3}\left(\mathrm{H}_{2} \mathrm{O}\right)_{6}\right] \cdot \mathrm{nH}_{2} \mathrm{O}$, are also based on the (6,3)-2D honeycomb lattice and contain 12 crystallization $\mathrm{H}_{2} \mathrm{O}$ molecules for the larger $\mathrm{Ln}(\mathrm{III})$ ions (La to Er, phase I) or 8 water molecules for the smallest ions ( $\mathrm{Yb}$ and Tm, phase II). These two phases also differ in the disposition of the water molecules and in the spatial orientation of the bromanilato ligands $[36,37]$.

For the nitranilato ligand $\left(\mathrm{X}=\mathrm{NO}_{2}\right)$, the larger size of the nitro group compared to $\mathrm{H}, \mathrm{Cl}$ and $\mathrm{Br}$ prevented, in our case, the formation of the (6,3)-2D honeycomb lattice and led to the formation of nitranilato-bridged dimers formulated as $\left[\mathrm{Ln}_{2}\left(\mathrm{C}_{6} \mathrm{O}_{4}\left(\mathrm{NO}_{2}\right)_{2}\right)_{3}\left(\mathrm{H}_{2} \mathrm{O}\right)_{10}\right] \cdot 6 \mathrm{H}_{2} \mathrm{O}$ although only for the intermediate $\mathrm{Ln}(\mathrm{III})$ ions (Sm-Er) [36,38]. 
Finally, the asymmetric chlorocyananilato ligand $\left(\mathrm{C}_{6} \mathrm{O}_{4}(\mathrm{CN}) \mathrm{Cl}^{2-}\right)$ has very recently been used with Dy(III) and $\mathrm{H}_{2} \mathrm{O}$ to prepare compound $\left[\mathrm{H}_{3} \mathrm{O}\right]\left[\mathrm{Dy}\left(\mathrm{C}_{6} \mathrm{O}_{4}(\mathrm{CN}) \mathrm{Cl}_{2}\left(\mathrm{H}_{2} \mathrm{O}\right)\right] \cdot 4 \mathrm{H}_{2} \mathrm{O}\right.$ that presents a very unusual square (4,4)-2D lattice [39].

All these previous results have been obtained using water as solvent. In fact, until very recently, the only example obtained with other solvent was compound $\left[\operatorname{Pr}_{2}\left(\mathrm{C}_{6} \mathrm{O}_{4} \mathrm{Cl}_{2}\right)_{3}(\mathrm{EtOH})_{6}\right] \cdot 2 \mathrm{EtOH}$, that also presents a structure based on the $(6,3)-2 \mathrm{D}$ honeycomb lattice although with very large distortions of the hexagonal cavities that appear as rectangles [40]. In the last two years our group has prepared a number of anilato-based Ln(III) compounds using different solvents with high coordinating capacity towards $\mathrm{Ln}$ (III) ions [41]. These studies include compounds as [ $\left.\mathrm{Er}_{2}\left(\mathrm{C}_{6} \mathrm{O}_{4} \mathrm{Br}_{2}\right)_{3}(\mathrm{DMSO})_{4}\right] \cdot 2 \mathrm{DMSO} \cdot 2 \mathrm{H}_{2} \mathrm{O}$ and $\left[\mathrm{Er}_{2}\left(\mathrm{C}_{6} \mathrm{O}_{4} \mathrm{Br}_{2}\right)_{3}(\mathrm{DMF})_{6}\right]$ [37] that present the same $(6,3)-2 \mathrm{D}$ topology but with rectangular cavities (in the DMF compound) or very distorted hexagonal ones (in the DMSO compound) and with a coordination number of eight (compared to nine for the $\mathrm{H}_{2} \mathrm{O}$ derivative). A larger study of the role of the solvent performed with the chloranilato ligand and $\mathrm{Er}(\mathrm{III})$ in the series of compounds $\left[\mathrm{Er}_{2}\left(\mathrm{C}_{6} \mathrm{O}_{4} \mathrm{Cl}_{2}\right)_{3}\left(\mathrm{H}_{2} \mathrm{O}\right)_{6}\right] \cdot 10 \mathrm{H}_{2} \mathrm{O},\left[\mathrm{Er}_{2}\left(\mathrm{C}_{6} \mathrm{O}_{4} \mathrm{Cl}_{2}\right)_{3}(\mathrm{DMF})_{6}\right]$, $\left[\mathrm{Er}_{2}\left(\mathrm{C}_{6} \mathrm{O}_{4} \mathrm{Cl}_{2}\right)_{3}(\mathrm{DMA})_{4}\right] \cdot 5 \mathrm{H}_{2} \mathrm{O}(\mathrm{DMA}=$ dimethylacetamide $),\left[\mathrm{Er}_{2}\left(\mathrm{C}_{6} \mathrm{O}_{4} \mathrm{Cl}_{2}\right)_{3}(\mathrm{DMSO})_{4}\right] \cdot 2 \mathrm{DMSO} \cdot 2 \mathrm{H}_{2} \mathrm{O}$, $\left[\mathrm{Er}_{2}\left(\mathrm{C}_{6} \mathrm{O}_{4} \mathrm{Cl}_{2}\right)_{3}(\mathrm{FMA})_{6}\right] \cdot 4 \mathrm{FMA} \cdot 2 \mathrm{H}_{2} \mathrm{O}(\mathrm{FMA}=$ formamide $)$ and $\left[\mathrm{Er}_{2}\left(\mathrm{C}_{6} \mathrm{O}_{4} \mathrm{Cl}_{2}\right)_{3}(\mathrm{HMPA})\left(\mathrm{H}_{2} \mathrm{O}\right)_{3}\right] \cdot \mathrm{H}_{2} \mathrm{O}$ (HMPA = hexamethylphosphormamide) showed that the size and steric hindrance of the solvent determines the coordination number and geometry, the size and shape of the cavities and, accordingly, the presence of solvent and water molecules in the cavities [42]. All these results indicate that the solvent plays a very important role in the final structure. Very recently we have also prepared a series formulated as: $\left[\mathrm{Ln}_{2}\left(\mathrm{C}_{6} \mathrm{O}_{4} \mathrm{Br}_{2}\right)_{3}(\mathrm{DMSO})_{\mathrm{n}}\right] \cdot 2 \mathrm{DMSO} \cdot \mathrm{mH}_{2} \mathrm{O}$ with $\mathrm{n}=6$ and $\mathrm{m}=0$ for $\mathrm{Ln}=\mathrm{La}-\mathrm{Gd}$ and $\mathrm{n}=4$ and $\mathrm{m}=2$ for $\mathrm{Ln}=\mathrm{Tb}-\mathrm{Yb}$ [43]. In this series, as previously observed in the series $\left[\mathrm{Ln}_{2}\left(\mathrm{C}_{6} \mathrm{O}_{4} \mathrm{X}_{2}\right)_{3}\left(\mathrm{H}_{2} \mathrm{O}\right)_{6}\right] \cdot \mathrm{nH}_{2} \mathrm{O}\left(\mathrm{X}=\mathrm{Cl}, \mathrm{Br}\right.$ and $\left.\mathrm{NO}_{2}\right)$, the size of the $\mathrm{Ln}(\mathrm{III})$ ion plays a key structural role. Finally, also very recently, we have combined the asymmetric chlorocyananilato ligand, $\left(\mathrm{C}_{6} \mathrm{O}_{4}(\mathrm{CN}) \mathrm{Cl}\right)^{2-}$, with different $\mathrm{Ln}(\mathrm{III})$ ions as $\mathrm{Ce}(\mathrm{III}), \mathrm{Pr}(\mathrm{III})$ and $\mathrm{Yb}(\mathrm{III})$ using DMF and DMSO as solvents to prepare the compounds $\left[\mathrm{Ce}_{2}\left(\mathrm{C}_{6} \mathrm{O}_{4}(\mathrm{CN}) \mathrm{Cl}\right)_{3}(\mathrm{DMF})_{6}\right] \cdot 2 \mathrm{H}_{2} \mathrm{O}(\mathrm{I}),\left[\operatorname{Pr}_{2}\left(\mathrm{C}_{6} \mathrm{O}_{4}(\mathrm{CN}) \mathrm{Cl}\right)_{3}(\mathrm{DMF})_{6}\right]$ (II), $\left[\mathrm{Pr}_{2}\left(\mathrm{C}_{6} \mathrm{O}_{4}(\mathrm{CN}) \mathrm{Cl}\right)_{3}(\mathrm{DMSO})_{6}\right]$ (III) and $\left[\mathrm{Yb}_{2}\left(\mathrm{C}_{6} \mathrm{O}_{4}(\mathrm{CN}) \mathrm{Cl}\right)_{3}(\mathrm{DMSO})_{4}\right] \cdot 2 \mathrm{H}_{2} \mathrm{O}$ (IV) [39]. These four compounds showed some hints about the role of the solvent and the size of the $\operatorname{Ln}(\mathrm{III})$ in the final structure, but, given the reduced number of compounds did not allow to extract deeper conclusions.

Here we extend this study with the asymmetric chlorocyananilato ligand and dimethylformamide (DMF) and dimethylsulfoxide (DMSO) as solvents with four more $\mathrm{Ln}(\mathrm{III})$ ions (Ce, $\mathrm{Nd}$, Dy and $\mathrm{Ho})$ to prepare five new compounds formulated as: $\left[\mathrm{Nd}_{2}\left(\mathrm{C}_{6} \mathrm{O}_{4}(\mathrm{CN}) \mathrm{Cl}\right)_{3}(\mathrm{DMF})_{6}\right](\mathbf{1})\left[\mathrm{Dy}_{2}\left(\mathrm{C}_{6} \mathrm{O}_{4}\right.\right.$ $\left.(\mathrm{CN}) \mathrm{Cl})_{3}(\mathrm{DMF})_{6}\right] \cdot 4 \mathrm{H}_{2} \mathrm{O}(2),\left[\mathrm{Ho}_{2}\left(\mathrm{C}_{6} \mathrm{O}_{4}(\mathrm{CN}) \mathrm{Cl}\right)_{3}(\mathrm{DMF})_{6}\right] \cdot 2 \mathrm{H}_{2} \mathrm{O}(3)$, and $\left[\mathrm{Ln}_{2}\left(\mathrm{C}_{6} \mathrm{O}_{4}(\mathrm{CN}) \mathrm{Cl}\right)_{3}(\mathrm{DMSO})_{6}\right]$ with $\mathrm{Ln}=\mathrm{Ce}(4)$ and $\mathrm{Nd}(5)$. These five compounds, together with the four compounds previously reported with the same ligand and identical stoichiometry: $\left[\mathrm{Ce}_{2}\left(\mathrm{C}_{6} \mathrm{O}_{4}(\mathrm{CN}) \mathrm{Cl}\right)_{3}(\mathrm{DMF})_{6}\right] \cdot 2 \mathrm{H}_{2} \mathrm{O}$ (I), $\left[\mathrm{Pr}_{2}\left(\mathrm{C}_{6} \mathrm{O}_{4}(\mathrm{CN}) \mathrm{Cl}\right)_{3}(\mathrm{DMF})_{6}\right](\mathrm{II}),\left[\mathrm{Pr}_{2}\left(\mathrm{C}_{6} \mathrm{O}_{4}(\mathrm{CN}) \mathrm{Cl}\right)_{3}(\mathrm{DMSO})_{6}\right]$ (III) and $\left[\mathrm{Yb}_{2}\left(\mathrm{C}_{6} \mathrm{O}_{4}(\mathrm{CN}) \mathrm{Cl}\right)_{3}\right.$ (DMSO) $)_{4} \cdot 2 \mathrm{H}_{2} \mathrm{O}$ (IV) [39] will allow us to obtain a deeper knowledge of the role played by both factors: the size of the $\mathrm{Ln}(\mathrm{III})$ ion and the solvent (DMF and DMSO) with the asymmetric ligand chlorocyananilato.

\section{Results and Discussion}

\subsection{Syntheses of the Complexes}

Compounds 1 and 2 were synthesized by carefully layering solutions containing the $\operatorname{Ln}(\mathrm{III})$ ion, dissolved in DMF, and the asymmetric chlorocyananilato ligand, as its tetraphenylphosphonium salt, dissolved in methanol. Compounds 3-5 were synthesized in the same way but using the monopotassium salt of the asymmetric chlorocyananilato ligand dissolved in the corresponding solvent: DMF (for 3) and DMSO (for 4 and 5). As expected, given the strong affinity towards Ln(III) ions of the used solvents (DMF and DMSO) [41], they appear in all cases coordinated to the Ln(III) 
ions. The used synthetic method allowed a slow diffusion of the reagents that resulted in good quality single crystals for the determination of the X-ray structure in all cases.

\subsection{X-ray Power Diffraction (XRPD)}

All the samples were analyzed by XRPD to confirm the isostructurality with the solved structures and the phase purity. In all cases the experimental diffractograms are similar to the simulated ones from the single crystal X-ray structure (see supporting information, Figures S1-S5), although the crystallinity of compounds $\mathbf{2}$ and $\mathbf{3}$ is very poor due to the loss of the water crystallization molecules.

\subsection{IR Spectroscopy}

The IR spectra of the five compounds show the expected bands attributed to the ligands and the coordinated solvent molecules (see supporting information, Figures S6-S10 and Table S1).

\subsection{Description of the Structures}

Structure of $\left[\mathrm{Nd}_{2}\left(\mathrm{C}_{6} \mathrm{O}_{4}(\mathrm{CN}) \mathrm{Cl}\right)_{3}(\mathrm{DMF})_{6}\right]$ (1). Compound 1 crystallizes in the monoclinic $P 2_{1} / n$ space group (Table 1). The asymmetric unit (Figure 1a) contains one $\mathrm{Nd}(\mathrm{III})$ ion, three coordinated DMF molecules and one and a half chlorocyananilato ligands. This asymmetric unit corresponds to the formula $\left[\mathrm{Nd}_{2}\left(\mathrm{C}_{6} \mathrm{O}_{4}(\mathrm{CN}) \mathrm{Cl}\right)_{3}(\mathrm{DMF})_{6}\right]$. There is an inversion centre in the centre of one of the anilato rings that generates a disorder between the $\mathrm{CN}$ and $\mathrm{Cl}$ groups with occupancies of $\frac{1}{2}$ in each position.

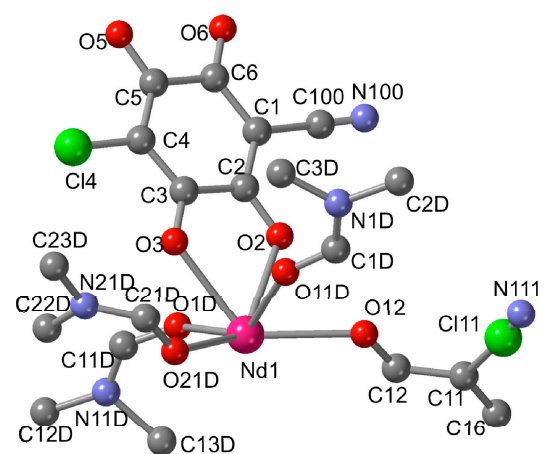

(a)

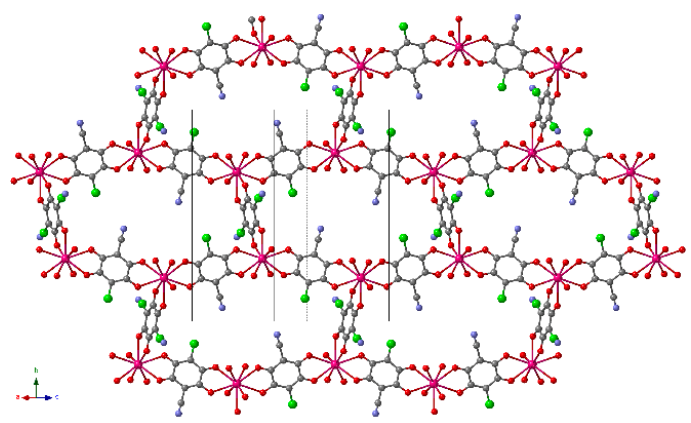

(c)

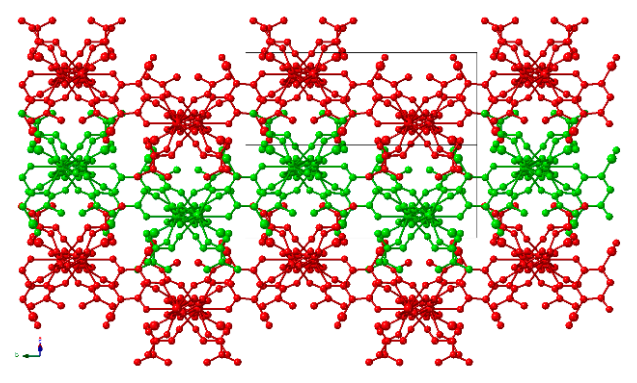

(b)

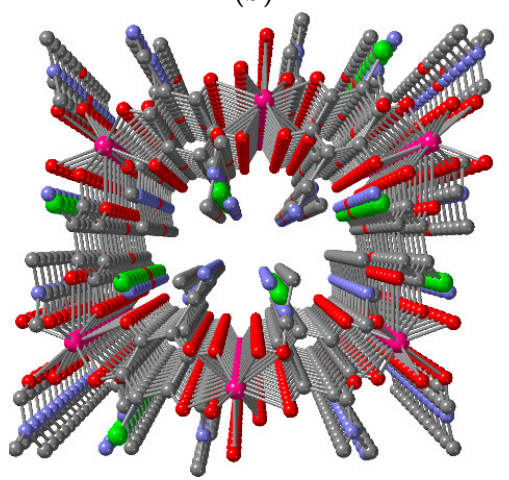

(d)

Figure 1. (a) Asymmetric unit of compound 1 with the labelling scheme. (b) Side view of the corrugated layers in compound 1. Consecutive layers are coloured in green and red for clarity. (c) View of a layer in $\mathbf{1}$ (For the dimethylformamide (DMF) molecules only the oxygen atoms are shown). (d) Perspective view of one rectangular channel along the [101] direction in compound 1. Colour code: $\mathrm{Nd}=$ pink, $\mathrm{Cl}=$ green, $\mathrm{C}=$ grey, $\mathrm{O}=$ red, $\mathrm{N}=$ dark blue. $\mathrm{H}$ atoms have been omitted for clarity. 
Table 1. Crystal data and structure refinement of compounds $\left[\mathrm{Nd}_{2}\left(\mathrm{C}_{6} \mathrm{O}_{4}(\mathrm{CN}) \mathrm{Cl}\right)_{3}(\mathrm{DMF})_{6}\right](\mathbf{1})$, $\left[\mathrm{Dy}_{2}\left(\mathrm{C}_{6} \mathrm{O}_{4}(\mathrm{CN}) \mathrm{Cl}\right)_{3}(\mathrm{DMF})_{6}\right] \cdot 4 \mathrm{H}_{2} \mathrm{O}(2),\left[\mathrm{Ho}_{2}\left(\mathrm{C}_{6} \mathrm{O}_{4}(\mathrm{CN}) \mathrm{Cl}\right)_{3}(\mathrm{DMF})_{6}\right] \cdot 2 \mathrm{H}_{2} \mathrm{O}(3)$ and $\left[\mathrm{Ln}_{2}\left(\mathrm{C}_{6} \mathrm{O}_{4}(\mathrm{CN}) \mathrm{Cl}\right)_{3}\right.$ $\left.(\mathrm{DMSO})_{6}\right]$ with $\mathrm{Ln}=\mathrm{Ce}(4)$ and $\mathrm{Nd}(5)$.

\begin{tabular}{|c|c|c|c|c|c|}
\hline & 1 & 2 & 3 & 4 & 5 \\
\hline & $\mathrm{C}_{39} \mathrm{H}_{42} \mathrm{Cl}_{3}$ & $\mathrm{C}_{39} \mathrm{H}_{50} \mathrm{Cl}_{3}$ & $\mathrm{C}_{39} \mathrm{H}_{46} \mathrm{Cl}_{3}$ & $\mathrm{C}_{33} \mathrm{H}_{36} \mathrm{Cl}_{3}$ & $\mathrm{C}_{33} \mathrm{H}_{36} \mathrm{Cl}_{3}$ \\
\hline Formula & $\mathrm{N}_{9} \mathrm{O}_{18} \mathrm{Nd}_{2}$ & $\mathrm{~N}_{9} \mathrm{O}_{22} \mathrm{Dy}_{2}$ & $\mathrm{~N}_{9} \mathrm{O}_{20} \mathrm{Ho}_{2}$ & $\mathrm{~N}_{3} \mathrm{O}_{18} \mathrm{~S}_{6} \mathrm{Ce}_{2}$ & $\mathrm{~N}_{3} \mathrm{O}_{18} \mathrm{~S}_{6} \mathrm{Nd}_{2}$ \\
\hline F. Wt. & 1319.64 & 1428.22 & 1397.05 & 1341.63 & 1349.88 \\
\hline Space group (\#) & $P 2_{1} / n(14)$ & C2/c (15) & C2/c (15) & $P 2_{1} / n(14)$ & $P 2_{1} / n(14)$ \\
\hline Crystal system & Monoclinic & Monoclinic & Monoclinic & Monoclinic & Monoclinic \\
\hline$a(\AA)$ & $10.5126(5)$ & $13.6849(3)$ & $13.8612(6)$ & $9.5974(2)$ & $9.6212(3)$ \\
\hline$b(\AA)$ & $18.8316(10)$ & $22.8267(6)$ & $23.0470(10)$ & $16.4105(3)$ & $16.3828(4)$ \\
\hline$c(\AA)$ & $12.7477(5)$ & $17.7221(4)$ & $17.9615(8)$ & $15.3719(3)$ & $15.2790(3)$ \\
\hline$\alpha\left(^{\circ}\right)$ & 90 & 90 & 90 & 90 & 90 \\
\hline$\beta\left(^{\circ}\right)$ & $97.445(5)$ & $98.349(2)$ & $98.363(4)$ & $91.111(2)$ & 91.989 \\
\hline$\gamma\left({ }^{\circ}\right)$ & 90 & 90 & 90 & 90 & 90 \\
\hline$V / \AA 3$ & $2502.4(2)$ & $5477.4(2)$ & $5676.9(4)$ & $2420.59(8)$ & $2406.86(11)$ \\
\hline Z & 2 & 4 & 4 & 2 & 2 \\
\hline$T(K)$ & 120 & 120 & 120 & 120 & 120 \\
\hline$\rho_{\text {calc }} / \mathrm{g} \mathrm{cm}^{-3}$ & 1.751 & 1.722 & 1.630 & 1.791 & 1.812 \\
\hline$\mu / \mathrm{mm}^{-1}$ & 2.291 & 2.936 & 2.983 & 2.351 & 2.630 \\
\hline$F(000)$ & 1308 & 2792 & 2736 & 1252 & 1260 \\
\hline $\mathrm{R}($ int $)$ & 0.0558 & 0.0283 & 0.0207 & 0.0302 & 0.0573 \\
\hline$\theta$ range (deg) & $3.400-25.040$ & $3.360-25.035$ & $3.324-25.045$ & $3.267-28.009$ & $3.267-25.036$ \\
\hline Total reflections & 9854 & 10265 & 11058 & 9482 & 15285 \\
\hline Unique reflections & 4419 & 4835 & 5005 & 4858 & 4251 \\
\hline Data with $I>2 \sigma(I)$ & 3048 & 4155 & 4527 & 4062 & 3221 \\
\hline $\mathrm{N}_{\mathrm{var}}$ & 334 & 352 & 361 & 338 & 347 \\
\hline $\mathrm{R}_{1}{ }^{\mathrm{a}}$ on $I>2 \sigma(I)$ & 0.0718 & 0.0376 & 0.0296 & 0.0612 & 0.0553 \\
\hline$w \mathrm{R}_{2}{ }^{\mathrm{b}}($ all $)$ & 0.1808 & 0.0988 & 0.0767 & 0.1509 & 0.1375 \\
\hline $\mathrm{GOF}^{\mathrm{c}}$ on $\mathrm{F}^{2}$ & 1.061 & 1.041 & 1.078 & 1.066 & 1.029 \\
\hline$\Delta \rho_{\max }\left(\mathrm{e}^{-3}\right)$ & 1.644 & 1.354 & 0.836 & 2.088 & 2.424 \\
\hline$\Delta \rho_{\min }\left(\mathrm{e}^{-3}\right)$ & -1.581 & -1.021 & -0.561 & -1.314 & -1.216 \\
\hline
\end{tabular}

The structure of $\mathbf{1}$ presents corrugated layers parallel to the (10-1) plane (Figure $1 \mathrm{~b}$ ) with a $(6,3)-2 \mathrm{D}$ honeycomb topology (Figure 1c) where the hexagons are so distorted that they can rather be described as parallel rectangles packed in a brick-wall mode (Figure 1c). The large distortions of the cavities are evidenced by the three Nd-Nd distances along the diagonals of the cavities (21.63(4), 17.54(2) and $12.030(2) \AA)$ and by the corresponding Nd-Nd-Nd angles $\left(85.10^{\circ}, 114.53^{\circ}\right.$ and $\left.157.90^{\circ}\right)$. The rectangles are formed by six $\mathrm{Nd}(\mathrm{III})$ centres in the vertex connected through bis-bidentate chlorocyananilato bridges in the sides. When viewed along the [100] direction, the layers form rectangular channels although with very little empty space (Figure $1 \mathrm{~d}$ ).

The coordination environment around the $\mathrm{Nd}(\mathrm{III})$ ions is a capped square anti-prism geometry (see below) formed by three chelate chlorocyananilato ligands and three oxygen atoms from three DMF molecules (Figure 1a). The Nd-O bond distances (Table 2) are similar to those observed in the related Nd-containing anilato-based compounds: $\left[\mathrm{Nd}_{2}\left(\mathrm{C}_{6} \mathrm{O}_{4} \mathrm{X}_{2}\right)_{3}\left(\mathrm{H}_{2} \mathrm{O}\right)_{6}\right] \cdot \mathrm{nH}_{2} \mathrm{O}(\mathrm{X}=\mathrm{H}, \mathrm{n}=18 ; \mathrm{X}=\mathrm{Cl}, \mathrm{n}=14$ and $\mathrm{X}=\mathrm{Br}, \mathrm{n}=12)[28,36]$ and in $\left[\mathrm{Nd}_{2}\left(\mathrm{C}_{6} \mathrm{O}_{4} \mathrm{Br}_{2}\right)_{3}(\mathrm{DMSO})_{6}\right] \cdot 2 \mathrm{DMSO}[43]$. As expected, the $\mathrm{Nd}-\mathrm{O}_{\text {anilato }}$ bond distances are longer than the $\mathrm{Nd}-\mathrm{O}_{\mathrm{DMF}}$ ones due to the chelating coordination mode of the chlorocyananilato ligand.

Structure of $\left[\operatorname{Ln}_{2}\left(\mathrm{C}_{6} \mathrm{O}_{4}(\mathrm{CN}) \mathrm{Cl}\right)_{3}(\mathrm{DMF})_{6}\right] \cdot \mathrm{nH}_{2} \mathrm{O} ; \mathrm{Ln}=\mathrm{Dy}, \mathrm{n}=4$ (2) and $\mathrm{Ln}=\mathrm{Ho}, \mathrm{n}=\mathbf{2}$ (3). Compounds $\mathbf{2}$ and 3 are isostructural and both crystallize in the monoclinic C2/c space group (Table 1). Given the similarity between both structures, we will only describe the structure of compound 2 although we will compare all the structures in detail below. The asymmetric unit of 2 (Figure 2a) contains one Dy(III) ion (Ho(III) in 3), three coordinated DMF molecules, three halves chlorocyananilato 
ligands and two crystallization water molecules (three water molecules with occupancy $1 / 3$ in compound 3). This asymmetric unit corresponds to the formula $\left[\mathrm{Ln}_{2}\left(\mathrm{C}_{6} \mathrm{O}_{4}(\mathrm{CN}) \mathrm{Cl}\right)_{3}(\mathrm{DMF})_{6}\right] \cdot \mathrm{nH}_{2} \mathrm{O}$ with $\mathrm{Ln}=\mathrm{Dy}, \mathrm{n}=4$ in $\mathbf{2}$ and $\mathrm{Ln}=\mathrm{Ho}, \mathrm{n}=2$ in 3 . There is an inversion centre in the centre of the three anilato rings that generates a disorder between the $\mathrm{CN}$ and $\mathrm{Cl}$ groups with occupancies of $\frac{1}{2}$ each.

Table 2. Bond distances $(\AA)$ for compounds $\left[\mathrm{Nd}_{2}\left(\mathrm{C}_{6} \mathrm{O}_{4}(\mathrm{CN}) \mathrm{Cl}\right)_{3}(\mathrm{DMF})_{6}\right](\mathbf{1})$, $\left[\mathrm{Dy}_{2}\left(\mathrm{C}_{6} \mathrm{O}_{4}(\mathrm{CN}) \mathrm{Cl}\right)_{3}\right.$ $\left.(\mathrm{DMF})_{6}\right] \cdot 4 \mathrm{H}_{2} \mathrm{O}(2),\left[\mathrm{Ho}_{2}\left(\mathrm{C}_{6} \mathrm{O}_{4}(\mathrm{CN}) \mathrm{Cl}\right)_{3}(\mathrm{DMF})_{6}\right] \cdot 2 \mathrm{H}_{2} \mathrm{O}(3)$ and $\left[\operatorname{Ln}_{2}\left(\mathrm{C}_{6} \mathrm{O}_{4}(\mathrm{CN}) \mathrm{Cl}\right)_{3}(\mathrm{DMSO})_{6}\right]$ with $\mathrm{Ln}=\mathrm{Ce}(4)$ and $\mathrm{Nd}(5)$.

\begin{tabular}{cccccc}
\hline Bond $^{\mathbf{a}}$ & $\mathbf{1}$ & $\mathbf{2}$ & $\mathbf{3}$ & $\mathbf{4}$ & $\mathbf{5}$ \\
\hline Ln-O2 & $2.513(7)$ & $2.444(4)$ & $2.407(3)$ & $2.571(5)$ & $2.512(5)$ \\
Ln-O3 & $2.493(7)$ & $2.439(4)$ & $2.497(3)$ & $2.556(5)$ & $2.538(5)$ \\
Ln-O5 & $2.513(7)$ & $2.491(4)$ & $2.408(3)$ & $2.572(5)$ & $2.545(5)$ \\
Ln-O6 & $2.510(7)$ & $2.387(4)$ & $2.514(3)$ & $2.596(5)$ & $2.540(6)$ \\
Ln-O12 & $2.498(7)$ & $2.470(4)$ & $2.458(3)$ & $2.554(5)$ & $2.507(5)$ \\
Ln-O16 & $2.518(8)$ & $2.381(3)$ & $2.466(3)$ & $2.567(6)$ & $2.529(6)$ \\
<Ln-O\#> & 2.508 & 2.454 & 2.470 & 2.569 & 2.529 \\
Ln-O1D & $2.440(9)$ & $2.336(4)$ & $2.357(3)$ & $2.436(6)$ & $2.394(6)$ \\
Ln-O11D & $2.444(8)$ & $2.382(4)$ & $2.407(3)$ & $2.437(6)$ & $2.420(6)$ \\
Ln-O21D & $2.417(8)$ & $2.371(4)$ & $2.396(3)$ & $2.437(6)$ & $2.391(6)$ \\
<Ln-O\#D> & 2.434 & 2.363 & 2.387 & 2.437 & 2.402
\end{tabular}

a For compound 2: $\mathrm{O} 5=\mathrm{O} 12, \mathrm{O} 6=\mathrm{O} 13, \mathrm{O} 12=\mathrm{O} 22$ and $\mathrm{O} 16=\mathrm{O} 23$; for compound 3: $\mathrm{O} 3=\mathrm{O} 6, \mathrm{O} 5=\mathrm{O} 12, \mathrm{O} 6=\mathrm{O} 16$, $\mathrm{O} 12=\mathrm{O} 22$ and $\mathrm{O} 16=\mathrm{O} 26$.

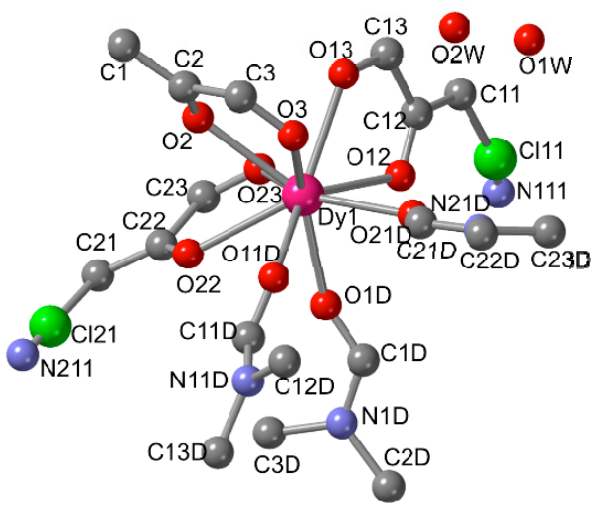

(a)

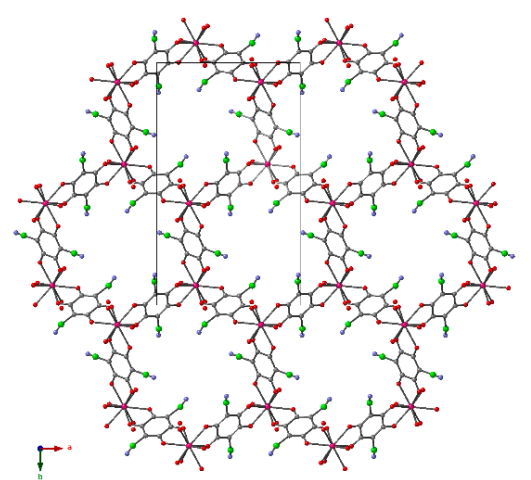

(c)

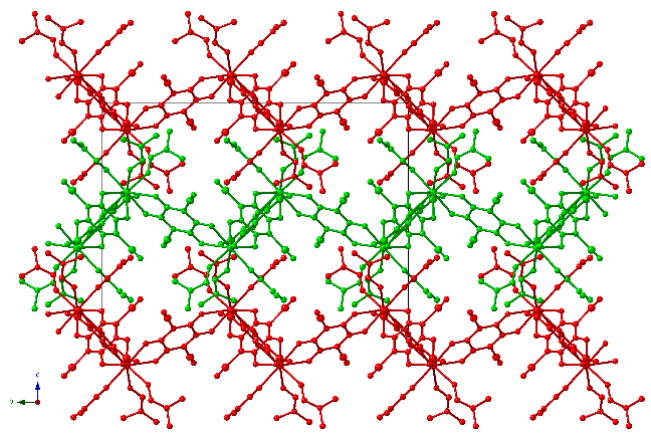

(b)

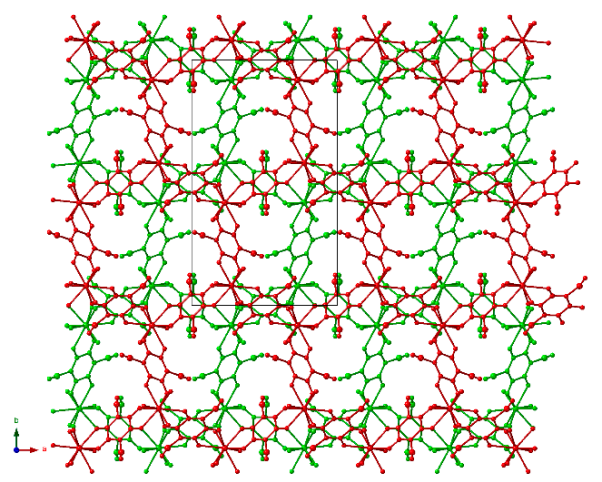

(d)

Figure 2. (a) Asymmetric unit of compound 2 with the labelling scheme. (b) Side view of the corrugated layers in compound 2. Consecutive layers are coloured in green and red for clarity. (c) View of a layer in 1. (d) View of two consecutive layers in $\mathbf{2}$ showing their alternating disposition. For the DMF molecules only the oxygen atoms are shown in $(\mathbf{c}, \mathbf{d})$. Colour code: $\mathrm{Dy}=$ pink, $\mathrm{Cl}=$ green, $\mathrm{C}=$ grey, $\mathrm{O}=$ red, $\mathrm{N}=$ dark blue. $\mathrm{H}$ atoms have been omitted for clarity. 
The structure of 2 and 3 shows very corrugated layers parallel to the (10-1) plane (Figure 2b) with a $(6,3)-2 D$ honeycomb topology (Figure 2c) with quite regular hexagonal cavities (the Ln-Ln distances are 16.237(7), 16.281(7) and 15.6506(8) $\AA$ in 2 and 16.436(13), 16.480(15) and 15.7904(11) $\AA$ in 3). The lack of planarity of these hexagonal cavities is confirmed by the three Ln-Ln-Ln angles inside the hexagon: $\left(98.19^{\circ}, 98.50^{\circ}\right.$ and $101.96^{\circ}$ for 2 and $98.15^{\circ}, 98.46^{\circ}$ and $102.23^{\circ}$ for 3$)$. These hexagons contain six Ln(III) ions in the vertex and six bis-bidentate chlorocyananilato bridges in the sides. Consecutive layers are disposed in an alternating way (Figure 2d), precluding the formation of channels. The coordination geometry around the Ln(III) ions can be described as a distorted square anti-prism (see below and Table 3) formed by three chelate chlorocyananilato ligands and three oxygen atoms from three DMF molecules (Figure 2a).

Table 3. SHAPE values for the 13 possible coordination geometries found for coordination number nine in compounds $\left[\mathrm{Nd}_{2}\left(\mathrm{C}_{6} \mathrm{O}_{4}(\mathrm{CN}) \mathrm{Cl}\right)_{3}(\mathrm{DMF})_{6}\right](\mathbf{1}),\left[\mathrm{Dy}_{2}\left(\mathrm{C}_{6} \mathrm{O}_{4}(\mathrm{CN}) \mathrm{Cl}\right)_{3}(\mathrm{DMF})_{6}\right] \cdot 4 \mathrm{H}_{2} \mathrm{O}(\mathbf{2})$, $\left[\mathrm{Ho}_{2}\left(\mathrm{C}_{6} \mathrm{O}_{4}(\mathrm{CN}) \mathrm{Cl}\right)_{3}(\mathrm{DMF})_{6}\right] \cdot 2 \mathrm{H}_{2} \mathrm{O}(3)$ and $\left[\mathrm{Ln}_{2}\left(\mathrm{C}_{6} \mathrm{O}_{4}(\mathrm{CN}) \mathrm{Cl}\right)_{3}(\mathrm{DMSO})_{6}\right]$ with $\mathrm{Ln}=\mathrm{Ce}(4)$ and $\mathrm{Nd}(5)$.

\begin{tabular}{ccccccc}
\hline Geometry & Symmetry & $\mathbf{1}$ & $\mathbf{2}$ & $\mathbf{3}$ & $\mathbf{4}$ & $\mathbf{5}$ \\
\hline EP-9 & $\mathrm{D}_{9 \mathrm{~h}}$ & 35.159 & 36.051 & 36.078 & 36.498 & 36.635 \\
OPY-9 & $\mathrm{C}_{8 \mathrm{v}}$ & 21.266 & 22.416 & 22.466 & 22.477 & 22.648 \\
HBPY-9 & $\mathrm{D}_{7 \mathrm{~h}}$ & 18.045 & 20.482 & 20.529 & 19.269 & 19.057 \\
JTC-9 & $\mathrm{C}_{3 \mathrm{v}}$ & 14.924 & 15.489 & 15.517 & 15.902 & 16.172 \\
JCCU-9 & $\mathrm{C}_{4 \mathrm{v}}$ & 9.355 & 10.612 & 10.580 & 10.849 & 10.831 \\
CCU-9 & $\mathrm{C}_{4 \mathrm{v}}$ & 7.898 & 9.589 & 9.561 & 9.618 & 9.703 \\
JCSAPR-9 & $\mathrm{C}_{4 \mathrm{v}}$ & 1.637 & 1.197 & 1.180 & 1.741 & 1.528 \\
CSAPR-9 & $\mathrm{C}_{\mathbf{4 v}}$ & $\mathbf{0 . 5 0 7}$ & $\mathbf{0 . 3 1 7}$ & $\mathbf{0 . 3 0 1}$ & $\mathbf{0 . 8 4 6}$ & $\mathbf{0 . 6 6 9}$ \\
JTCTPR-9 & $\mathrm{D}_{3 \mathrm{~h}}$ & 3.060 & 1.971 & 1.986 & 2.490 & 2.386 \\
TCTPR-9 & $\mathrm{D}_{3 \mathrm{~h}}$ & 1.162 & 0.884 & 0.884 & 0.934 & 0.908 \\
JTDIC-9 & $\mathrm{C}_{3 \mathrm{v}}$ & 12.573 & 13.277 & 13.250 & 11.695 & 12.101 \\
HH-9 & $\mathrm{C}_{2 \mathrm{v}}$ & 12.212 & 12.507 & 12.556 & 11.578 & 11.696 \\
MFF-9 & $\mathrm{C}_{\mathrm{s}}$ & 1.280 & 0.865 & 0.849 & 1.088 & 0.981 \\
\hline
\end{tabular}

EP-9 = Enneagon; OPY-9 = Octagonal pyramid; HBPY-9 = Heptagonal bipyramid; JTC-9 = Triangular cupola (J3) = trivacant cuboctahedron; JCCU-9 = Capped cube (Elongated square pyramid, J8); CCU-9 = Capped cube; JCSAPR-9 = Capped square antiprism (Gyroelongated square pyramid J10); CSAPR-9 $=$ Capped square antiprism; JTCTPR-9 = Tricapped trigonal prism (J51); TCTPR-9 = Tricapped trigonal prism; JTDIC-9 = Tridiminished icosahedron (J63); HH-9 = Hula-hoop; MFF-9 = Muffin. The minima values are indicated in bold.

The Ln-O bond distances (Table 2) are similar to those observed in the related Dy and Ho-containing anilato-based compounds: [ $\left.\mathrm{Ln}_{2}\left(\mathrm{C}_{6} \mathrm{O}_{4} \mathrm{X}_{2}\right)_{3}\left(\mathrm{H}_{2} \mathrm{O}\right)_{6}\right] \cdot \mathrm{nH}_{2} \mathrm{O}(\mathrm{Ln}=\mathrm{Dy}$ and Ho; $\mathrm{X}=\mathrm{H}$, $\mathrm{n}=18 ; \mathrm{X}=\mathrm{Cl}, \mathrm{n}=12$ and $\mathrm{X}=\mathrm{Br}, \mathrm{n}=12)$ [36] in $\left[\mathrm{Ln}_{2}\left(\mathrm{C}_{6} \mathrm{O}_{4}\left(\mathrm{NO}_{2}\right)_{2}\right)_{3}\left(\mathrm{H}_{2} \mathrm{O}\right)_{10}\right] \cdot 6 \mathrm{H}_{2} \mathrm{O}(\mathrm{Ln}=\mathrm{Dy}$ and Ho) $[36,38]$ and in $\left[\mathrm{Ln}_{2}\left(\mathrm{C}_{6} \mathrm{O}_{4} \mathrm{Br}_{2}\right)_{3}(\mathrm{DMSO})_{4}\right] \cdot 2 \mathrm{DMSO} \cdot 2 \mathrm{H}_{2} \mathrm{O}(\mathrm{Ln}=\mathrm{Dy}$ and Ho) [43]. As observed in compound 1, the $\mathrm{Ln}-\mathrm{O}_{\text {anilato }}$ bond distances are longer than the $\mathrm{Ln}-\mathrm{O}_{\mathrm{DMF}}$ ones due to the chelating coordination mode of the chlorocyananilato ligand.

Structure of $\left[\mathrm{Ln}_{2}\left(\mathrm{C}_{6} \mathrm{O}_{4}(\mathrm{CN}) \mathrm{Cl}\right)_{3}(\mathrm{DMSO})_{6}\right], \mathrm{Ln}=\mathrm{Ce}(4)$ and $\mathrm{Nd}(5)$. Compounds 4 and 5 are isostructural and, therefore, we will only describe the structure of compound 4 although we will compare both in detail below. Both compounds crystallize in the monoclinic $P 2_{1} / n$ space group (Table 1). The asymmetric unit of 4 (Figure 3a) contains one $\mathrm{Ce}(\mathrm{III})$ ion ( $\mathrm{Nd}(\mathrm{III})$ in 5 ), three coordinated DMSO molecules and one and a half chlorocyananilato ligands. This asymmetric unit corresponds to the formula $\left[\mathrm{Ln}_{2}\left(\mathrm{C}_{6} \mathrm{O}_{4}(\mathrm{CN}) \mathrm{Cl}\right)_{3}(\mathrm{DMSO})_{6}\right]$ with $\mathrm{Ln}=\mathrm{Ce}$ in 4 and $\mathrm{Nd}$ in 5 . The presence of an inversion centre in the centre of one anilato rings generates a disorder between the $\mathrm{CN}$ and $\mathrm{Cl}$ groups with occupancies of $\frac{1}{2}$ each.

Both compounds show corrugated layers (Figure $3 b$ ) with a $(6,3)-2 \mathrm{D}$ honeycomb topology (Figure 3c) formed by very distorted cavities that look like rectangles. These rectangles are packed in parallel rows in a brick-wall mode (Figure 3c), as observed in compound 1. The large distortions of the cavities are evidenced by the three Ln-Ln distances along the diagonals of the cavities (20.749(9), 19.439(17) and 11.039(3) $\AA$ in 4 and 20.469(10), 19.303(17) and 11.023(3) $\AA$ in 5) and by 
the corresponding Ln-Ln-Ln angles $\left(91.40^{\circ}, 100.67^{\circ}\right.$ and $164.41^{\circ}$ in 4 and $92.13^{\circ}, 100.46^{\circ}$ and $163.76^{\circ}$ in 5). As in 1, the rectangles are formed by six Ln(III) centres located in the vertex and by bis-bidentate chlorocyananilato bridges in the sides. These rectangles form channels along the [100] direction with very little empty space (Figure 3d).

The coordination environment around the $\mathrm{Ln}(\mathrm{III})$ ions is a capped square anti-prism geometry (see below and Table 3) formed by three chelate chlorocyananilato ligands and three oxygen atoms from three DMSO molecules (Figure 3a). The Ln-O bond distances (Table 2) are similar to those observed in the related $\mathrm{Ce}$ and $\mathrm{Nd}$-containing anilato-based compounds: $\left[\mathrm{Ln}_{2}\left(\mathrm{C}_{6} \mathrm{O}_{4} \mathrm{X}_{2}\right)_{3}\left(\mathrm{H}_{2} \mathrm{O}\right)_{6}\right] \cdot \mathrm{nH} \mathrm{H}_{2} \mathrm{O}(\mathrm{Ln}=\mathrm{Ce}$ and $\mathrm{Nd} ; \mathrm{X}=\mathrm{H}, \mathrm{n}=18 ; \mathrm{X}=\mathrm{Cl}, \mathrm{n}=14$ and $\mathrm{X}=\mathrm{Br}, \mathrm{n}=12)[28,36]$ in $\left[\mathrm{Ce}_{2}\left(\mathrm{C}_{6} \mathrm{O}_{4} \mathrm{Br}_{2}\right)_{3}(\mathrm{DMF})_{6}\right] \cdot 2 \mathrm{H}_{2} \mathrm{O}[39]$ and in $\left[\mathrm{Ln}_{2}\left(\mathrm{C}_{6} \mathrm{O}_{4} \mathrm{Br}_{2}\right)_{3}(\mathrm{DMSO})_{6}\right](\mathrm{Ln}=\mathrm{Ce}$ and $\mathrm{Nd})$ [43]. As observed in compounds 1-3, the $\mathrm{Nd}-\mathrm{O}_{\text {anilato }}$ bond distances are longer than the corresponding ones with the solvent molecules (DMSO in 4 and 5).

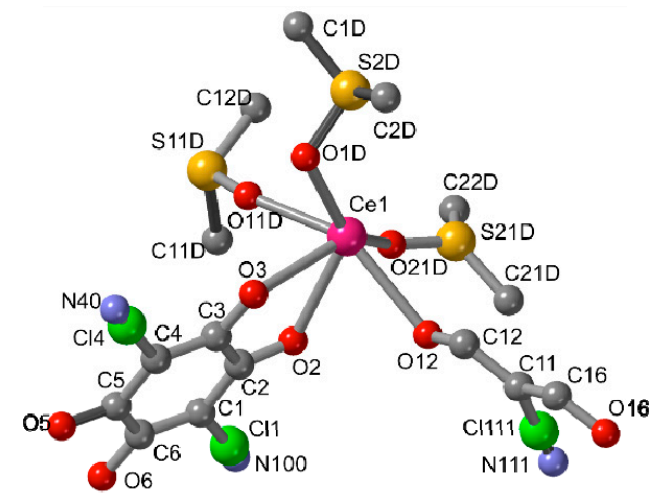

(a)

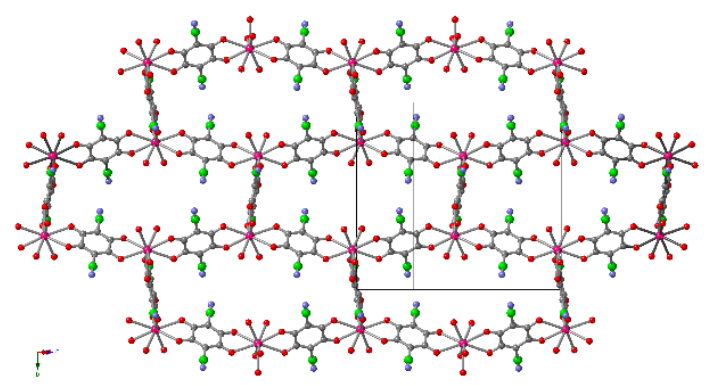

(c)

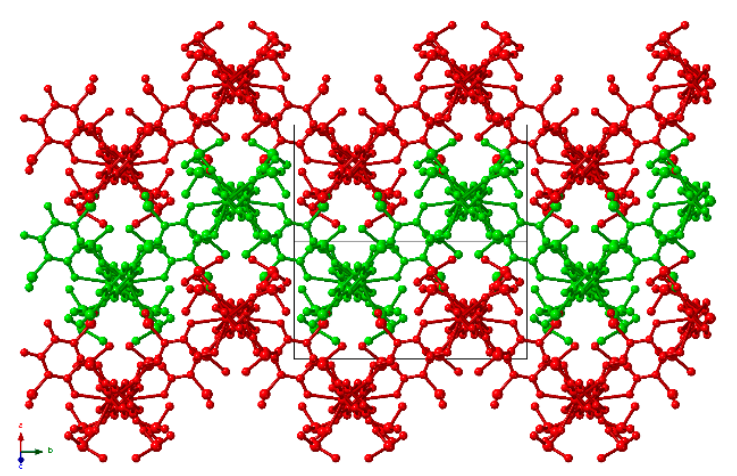

(b)

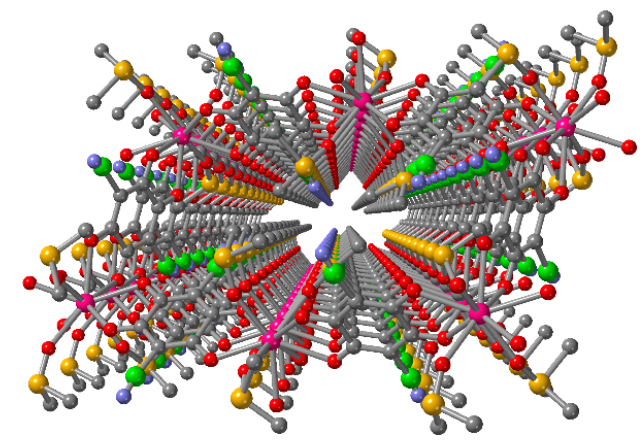

(d)

Figure 3. (a) Asymmetric unit of compound 4 with the labelling scheme. (b) Side view of the corrugated layers in compound 4. Consecutive layers are coloured in green and red for clarity. (c) View of a layer in 4 (For the DMSO molecules only the oxygen atoms are shown). (d) Perspective view of one rectangular channel along the [100] direction in compound 4. Colour code: $\mathrm{Ce}=$ pink, $\mathrm{Cl}=$ green, $\mathrm{C}=$ grey, $\mathrm{O}=$ red, $\mathrm{N}=$ dark blue. $\mathrm{H}$ atoms have been omitted for clarity.

\subsection{Comparison of the Structures}

In order to compare all the structures we have initially performed the analysis of the coordination geometry around the Ln(III) ions with the program SHAPE [44]. This analysis shows that the polyhedron that best describes the geometry around the $\operatorname{Ln}(\mathrm{III})$ ions in compounds $\mathbf{1 - 5}$ is a capped square anti-prism (CSAP, Table 3, Figure 4a-e) [45]. Although the five compounds show the same coordination geometry, there are important differences in the spatial disposition of the anilato ligands and the solvent molecules around the Ln(III). Thus, in compound $\mathbf{1}$ two of the three solvent molecules are located in the lower square face and the third one in the upper square face (Figure 4a) whereas in compounds 2 and 3 the three solvent molecules occupy one of the triangular faces (Figure $4 b, c$ ) and in compounds 4 and 5 the solvent molecules occupy three positions in the upper square face (Figure $4 \mathrm{~d}, \mathrm{e}$ ). 
The three anilato ligands also occupy different positions in the coordination environment (Figure 4a-e) resulting in different spatial orientations of the anilato ligands that lead to very different distortions of the hexagonal cavities (Figure $4 \mathrm{f}-\mathrm{j}$ ).

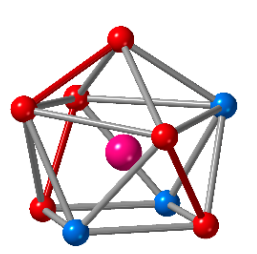

(a)

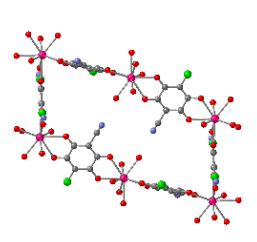

(f)

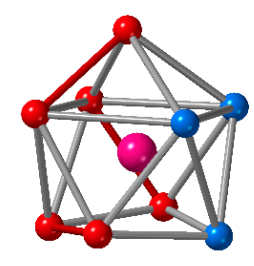

(b)

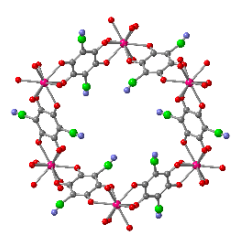

(g)

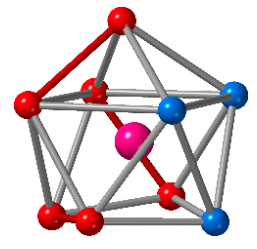

(c)

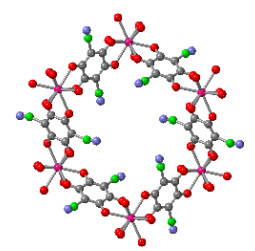

(h)

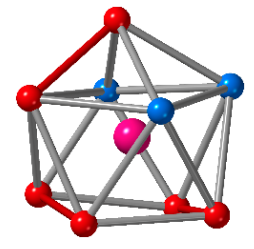

(d)

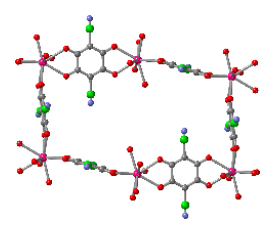

(i)

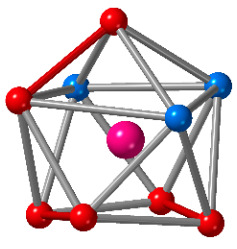

(e)

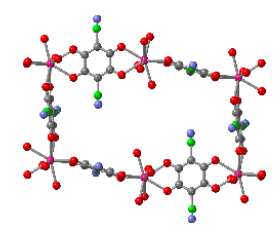

(j)

Figure 4. (a-e) Coordination polyhedra of the $\operatorname{Ln}(\mathrm{III})$ ions in compounds $\mathbf{1 - 5}$, respectively. The red lines correspond to the three chelating chlorocyananilato ligands. ( $\mathbf{f}-\mathbf{j})$ Cavities in compounds $\mathbf{1}-\mathbf{5}$, respectively. Colour code in $(\mathbf{a}-\mathbf{e})$ : $\mathrm{Ln}=$ pink, $\mathrm{O}_{\text {anilato }}=$ red and $\mathrm{O}_{\text {solvent }}=$ blue. Colour code in $(\mathbf{f}-\mathbf{j})$ : $\mathrm{Ln}=$ pink, $\mathrm{Cl}$ = green, $\mathrm{C}=$ grey, $\mathrm{O}=$ red, $\mathrm{N}=$ dark blue. $\mathrm{H}$ atoms have been omitted for clarity.

Thus, in compounds $1,4,5$ and in the previously reported $\left[\operatorname{Pr}_{2}\left(\mathrm{C}_{6} \mathrm{O}_{4}(\mathrm{CN}) \mathrm{Cl}\right)_{3}(\mathrm{DMF})_{6}\right](\mathrm{II})$ and $\left[\mathrm{Pr}_{2}\left(\mathrm{C}_{6} \mathrm{O}_{4}(\mathrm{CN}) \mathrm{Cl}\right)_{3}(\mathrm{DMSO})_{6}\right]$ (III) [39], the cavities contain four anilato ligands whose ring planes are orthogonal to the cavity plane (edge-on, E) and two whose ring planes are parallel to the cavity plane (face-on, F), resulting in a rectangular shape. In contrast, in compounds 2 and 3 and in the previously reported $\left[\mathrm{Ce}_{2}\left(\mathrm{C}_{6} \mathrm{O}_{4}(\mathrm{CN}) \mathrm{Cl}\right)_{3}(\mathrm{DMF})_{6}\right] \cdot 2 \mathrm{H}_{2} \mathrm{O}(\mathrm{I})$ and $\left[\mathrm{Yb}_{2}\left(\mathrm{C}_{6} \mathrm{O}_{4}(\mathrm{CN}) \mathrm{Cl}\right)_{3}(\mathrm{DMSO})_{4}\right] \cdot 2 \mathrm{H}_{2} \mathrm{O}$ (IV) [39], the six ligands have the same orientation and are tilted with respect to the cavity plane, resulting in quite regular hexagonal cavities. The most evident consequence of the change in the shape of the cavities is the presence or not of crystallization water molecules inside no matter the solvent used (DMF or DMSO). Thus, the compounds with hexagonal cavities (2, 3, I and IV) contain two or four crystallization water molecules, whereas the compounds with rectangular cavities $(\mathbf{1}, \mathbf{4}, \mathbf{5}$, II and III) do not contain water molecules, as a consequence of the larger size of the hexagonal cavities.

In order to study the influence of the $\mathrm{Ln}(\mathrm{III})$ size, we first consider the series of five compounds prepared with the asymmetric chlorocyananilato ligand and DFM as solvent: $\left[\mathrm{Nd}_{2}\left(\mathrm{C}_{6} \mathrm{O}_{4}(\mathrm{CN}) \mathrm{Cl}\right)_{3}\right.$ $\left.(\mathrm{DMF})_{6}\right](\mathbf{1}),\left[\mathrm{Dy}_{2}\left(\mathrm{C}_{6} \mathrm{O}_{4}(\mathrm{CN}) \mathrm{Cl}\right)_{3}(\mathrm{DMF})_{6}\right] \cdot 4 \mathrm{H}_{2} \mathrm{O}(2),\left[\mathrm{Ho}_{2}\left(\mathrm{C}_{6} \mathrm{O}_{4}(\mathrm{CN}) \mathrm{Cl}\right)_{3}(\mathrm{DMF})_{6}\right] \cdot 2 \mathrm{H}_{2} \mathrm{O}(3)$ and the previously reported $\left[\mathrm{Ce}_{2}\left(\mathrm{C}_{6} \mathrm{O}_{4}(\mathrm{CN}) \mathrm{Cl}\right)_{3}(\mathrm{DMF})_{6}\right] \cdot 2 \mathrm{H}_{2} \mathrm{O}(\mathrm{I})$ and $\left[\mathrm{Pr}_{2}\left(\mathrm{C}_{6} \mathrm{O}_{4}(\mathrm{CN}) \mathrm{Cl}\right)_{3}(\mathrm{DMF})_{6}\right]$ (II) [39]. In this series we can see up to three important structural changes as we move forward in the lanthanoids series: (i) the first change is observed when passing from Ce (compound I) to Pr (compound II) and implies a change from non-planar hexagonal cavities with the chair disposition in I to rectangular cavities with a spike disposition in II. (ii) A second structural change is observed between Pr (compound II) and $\mathrm{Nd}$ (compound 1) and implies a change from a rectangular spike-like layer in II to a rectangular brick wall one in 1. (iii) Finally, when passing from Nd (1) to Dy (2) and Ho (3) we observe a change from a rectangular brick wall layer in $\mathbf{1}$ to a hexagonal one in $\mathbf{2}$ and $\mathbf{3}$. Although the series is not complete yet, we can clearly see that the $\mathrm{Ln}(\mathrm{III})$ size is playing a key role in determining the size and shape of the cavities in the layered structures, while keeping the same $(6,3)-2 \mathrm{D}$ topology. With the exception of the cerium compound (I), the larger ions (Pr and $\mathrm{Nd}$ ) give rise to rectangular cavities whereas the smaller ions (Dy and Ho) give hexagonal cavities. Further experiments are in progress in order to determine the reason for this anomaly of $\mathrm{Ce}$. 
Interestingly, the series of four compounds prepared with DMSO: $\left[\mathrm{Ce}_{2}\left(\mathrm{C}_{6} \mathrm{O}_{4}(\mathrm{CN}) \mathrm{Cl}\right)_{3}(\mathrm{DMSO})_{6}\right]$ (4), $\left[\mathrm{Nd}_{2}\left(\mathrm{C}_{6} \mathrm{O}_{4}(\mathrm{CN}) \mathrm{Cl}\right)_{3}(\mathrm{DMSO})_{6}\right](5)$ and the previously reported $\left[\mathrm{Pr}_{2}\left(\mathrm{C}_{6} \mathrm{O}_{4}(\mathrm{CN}) \mathrm{Cl}\right)_{3}(\mathrm{DMSO})_{6}\right]$ (III) and $\left[\mathrm{Yb}_{2}\left(\mathrm{C}_{6} \mathrm{O}_{4}(\mathrm{CN}) \mathrm{Cl}\right)_{3}(\mathrm{DMSO})_{4}\right] \cdot 2 \mathrm{H}_{2} \mathrm{O}$ (IV) [39], shows a similar effect: the larger ions (Ce, $\mathrm{Pr}$ and $\mathrm{Nd}$ ) present rectangular cavities with no solvent molecules whereas the smaller ion (Yb) shows hexagonal cavities with two crystallization water molecules. In this last compound, the much smaller size of the $\mathrm{Yb}(\mathrm{III})$ ion has a second important effect: the reduction of the coordination number from nine to eight and, therefore, a change in the coordination geometry from capped square anti-prism to triangular dodecahedron [39].

\subsection{Magnetic Properties}

The product of the molar magnetic susceptibility times the temperature $\left(\chi_{m} \mathrm{~T}\right)$ per formula (two $\mathrm{Ln}(\mathrm{III})$ ions) in compounds $\left.\left[\mathrm{Nd}_{2}\left(\mathrm{C}_{6} \mathrm{O}_{4}(\mathrm{CN}) \mathrm{Cl}\right)_{3}(\mathrm{DMF})_{6}\right](\mathbf{1}), \mathrm{Dy}_{2}\left(\mathrm{C}_{6} \mathrm{O}_{4}(\mathrm{CN}) \mathrm{Cl}\right)_{3}(\mathrm{DMF})_{6}\right] \cdot 4 \mathrm{H}_{2} \mathrm{O}$ (2), $\left[\mathrm{Ho}_{2}\left(\mathrm{C}_{6} \mathrm{O}_{4}(\mathrm{CN}) \mathrm{Cl}\right)_{3}(\mathrm{DMF})_{6}\right] \cdot 2 \mathrm{H}_{2} \mathrm{O}(3),\left[\mathrm{Ce}_{2}\left(\mathrm{C}_{6} \mathrm{O}_{4}(\mathrm{CN}) \mathrm{Cl}\right)_{3}(\mathrm{DMSO})_{6}\right](4)$ and $\left[\mathrm{Nd}_{2}\left(\mathrm{C}_{6} \mathrm{O}_{4}(\mathrm{CN}) \mathrm{Cl}\right)_{3}\right.$ (DMSO) ${ }_{6}$ (5) is ca. 3.3, 28.8, 28.8, 1.6 and $3.2 \mathrm{~cm}^{3} \mathrm{~K} \mathrm{~mol}^{-1}$, respectively. These values are close to the expected ones for the corresponding Ln(III) ions (Table 4, Figure 5) [46]. When the samples are cooled, the $\chi_{\mathrm{m}} \mathrm{T}$ product decreases from room temperature in compounds 1,4 and 5 to reach values of $1.45,0.38$ and $1.20 \mathrm{~cm}^{3} \mathrm{~K} \mathrm{~mol}^{-1}$ at $2 \mathrm{~K}$, respectively (Figure 5). The $\chi_{\mathrm{m}} \mathrm{T}$ value in compounds 2 and 3 remains constant from room temperature down to ca. $50 \mathrm{~K}$ in 2 and ca. $120 \mathrm{~K}$ in 3 and show a progressive decrease at lower temperatures to reach values of 24.1 and $8.3 \mathrm{~cm}^{3} \mathrm{~K} \mathrm{~mol}^{-1}$ at $2 \mathrm{~K}_{\text {, }}$ respectively. The decrease observed in all the compounds at low temperature can be attributed to the depopulation of the high energy sublevels that appear due to the splitting of the ground levels caused by the ligand field effects. Note that the decrease might also include a very weak, although negligible, antiferromagnetic Ln-Ln coupling through the chlorocyananilato bridge.

Table 4. Magnetic properties of compounds $\left[\mathrm{Nd}_{2}\left(\mathrm{C}_{6} \mathrm{O}_{4}(\mathrm{CN}) \mathrm{Cl}\right)_{3}(\mathrm{DMF})_{6}\right](\mathbf{1}),\left[\mathrm{Dy}_{2}\left(\mathrm{C}_{6} \mathrm{O}_{4}(\mathrm{CN}) \mathrm{Cl}\right)_{3}\right.$ $\left.(\mathrm{DMF})_{6}\right] \cdot 4 \mathrm{H}_{2} \mathrm{O}(2),\left[\mathrm{Ho}_{2}\left(\mathrm{C}_{6} \mathrm{O}_{4}(\mathrm{CN}) \mathrm{Cl}\right)_{3}(\mathrm{DMF})_{6}\right] \cdot 2 \mathrm{H}_{2} \mathrm{O}(3)$ and $\left[\mathrm{Ln}_{2}\left(\mathrm{C}_{6} \mathrm{O}_{4}(\mathrm{CN}) \mathrm{Cl}\right)_{3}(\mathrm{DMSO})_{6}\right]$ with $\mathrm{Ln}=\mathrm{Ce}(4)$ and $\mathrm{Nd}(5)$.

\begin{tabular}{|c|c|c|c|c|c|c|}
\hline Compound & $\begin{array}{c}\chi_{m} T_{\text {experimental }}{ }^{a} \\
\left(\mathrm{~cm}^{3} \mathrm{~K} \mathrm{~mol}^{-1}\right)\end{array}$ & g & $\mathbf{S}$ & $\mathbf{L}$ & $\mathbf{J}$ & $\begin{array}{c}\chi_{m} T_{\text {calculated }} \\
\left(\mathrm{cm}^{3} \mathrm{~K} \mathrm{~mol}^{-1}\right)\end{array}$ \\
\hline$\left[\mathrm{Nd}_{2}\left(\mathrm{C}_{6} \mathrm{O}_{4}(\mathrm{CN}) \mathrm{Cl}\right)_{3}(\mathrm{DMF})_{6}\right](\mathbf{1})$ & 1.65 & $8 / 11$ & $3 / 2$ & 6 & $9 / 2$ & 1.64 \\
\hline$\left[\mathrm{Dy}_{2}\left(\mathrm{C}_{6} \mathrm{O}_{4}(\mathrm{CN}) \mathrm{Cl}\right)_{3}(\mathrm{DMF})_{6}\right] \cdot 4 \mathrm{H}_{2} \mathrm{O}(2)$ & 14.4 & $4 / 3$ & $5 / 2$ & 5 & $15 / 2$ & 14.17 \\
\hline$\left[\mathrm{Ho}_{2}\left(\mathrm{C}_{6} \mathrm{O}_{4}(\mathrm{CN}) \mathrm{Cl}\right)_{3}(\mathrm{DMF})_{6}\right] \cdot 2 \mathrm{H}_{2} \mathrm{O}(3)$ & 14.4 & $5 / 4$ & 2 & 6 & 8 & 14.07 \\
\hline$\left[\mathrm{Ce}_{2}\left(\mathrm{C}_{6} \mathrm{O} 4(\mathrm{CN}) \mathrm{Cl}\right)_{3}(\mathrm{DMSO})_{6}\right](4)$ & 0.8 & $6 / 7$ & $1 / 2$ & 3 & $5 / 2$ & 0.80 \\
\hline$\left[\mathrm{Nd}_{2}\left(\mathrm{C}_{6} \mathrm{O} 4(\mathrm{CN}) \mathrm{Cl}\right)_{3}(\mathrm{DMSO})_{6}\right](5)$ & 1.6 & $8 / 11$ & $3 / 2$ & 6 & $9 / 2$ & 1.64 \\
\hline
\end{tabular}

${ }^{\text {a }}$ Value per Ln(III) ion.

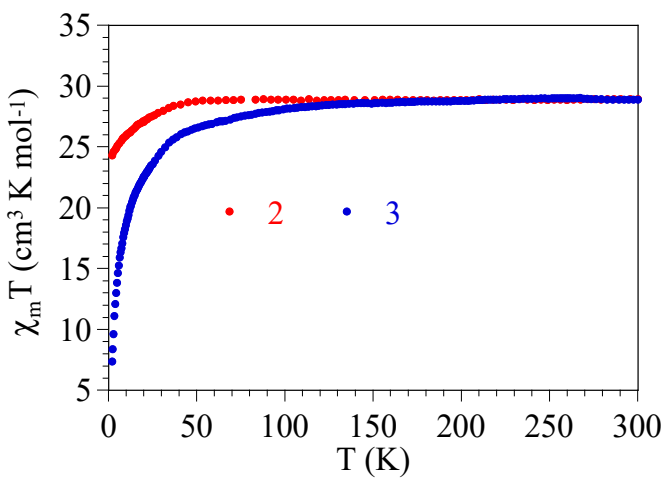

(a)

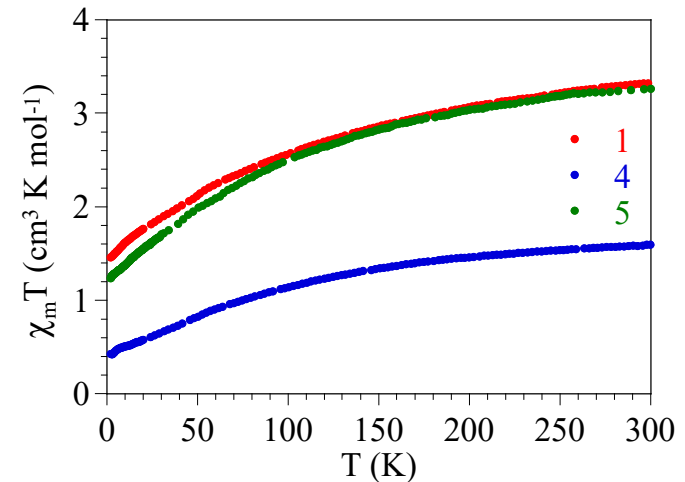

(b)

Figure 5. Thermal variation of the $\chi_{m} \mathrm{~T}$ product for compounds (a) 1, 4 and 5 and (b) 2 and 3 . 
The observed behaviour indicates that all compounds are paramagnetic and, therefore, that the chlorocyananilato bridge does not originate any noticeable magnetic coupling, as observed in all the reported compounds with this ligand and Ln(III) ions [36-39]. This magnetic isolation represents an advantage for the preparation of Ln-based single molecule magnets (SMM) in these series of compounds by simply diluting the paramagnetic centres with diamagnetic lanthanoids as $\mathrm{La}(\mathrm{III})$ and $\mathrm{Eu}(\mathrm{III})$. In fact, our preliminary results indicate that it is possible to obtain SMM and field-induced SMM using this very simple strategy and taking advantage of the isostructurality of many of these compounds.

\section{Experimental Section}

\subsection{Starting Materials}

The $\mathrm{Ln}(\mathrm{III})$ nitrates $\mathrm{Nd}\left(\mathrm{NO}_{3}\right)_{3} \cdot 6 \mathrm{H}_{2} \mathrm{O}, \mathrm{Dy}\left(\mathrm{NO}_{3}\right)_{3} \cdot 5 \mathrm{H}_{2} \mathrm{O}, \mathrm{Ho}\left(\mathrm{NO}_{3}\right)_{3} \cdot 5 \mathrm{H}_{2} \mathrm{O}$ and $\mathrm{Ce}\left(\mathrm{NO}_{3}\right)_{3} \cdot 6 \mathrm{H}_{2} \mathrm{O}$ as well as all the solvents used in this work, are commercially available and were used as received. The chlorocyananilato ligand, as $\left[\mathrm{Ph}_{4} \mathrm{P}_{2}\left[\mathrm{C}_{6} \mathrm{O}_{4}(\mathrm{CN}) \mathrm{Cl}\right] \cdot 2 \mathrm{H}_{2} \mathrm{O}\right.$ or $\mathrm{KH}\left[\mathrm{C}_{6} \mathrm{O}_{4}(\mathrm{CN}) \mathrm{Cl}\right]$, was prepared following the literature [47].

\subsection{Synthesis of $\left[\mathrm{Nd}_{2}\left(\mathrm{C}_{6} \mathrm{O}_{4}(\mathrm{CN}) \mathrm{Cl}\right)_{3}(\mathrm{DMF})_{6}\right](\mathbf{1})$}

Compound 1 was obtained as single crystals by carefully layering, at room temperature, a solution of $\left[\mathrm{Ph}_{4} \mathrm{P}_{2}\left[\mathrm{C}_{6} \mathrm{O}_{4}(\mathrm{CN}) \mathrm{Cl}\right] \cdot 2 \mathrm{H}_{2} \mathrm{O}(18.25 \mathrm{mg}, 0.02 \mathrm{mmol})\right.$ in $5 \mathrm{~mL}$ of methanol, on top of a solution of $\mathrm{Nd}\left(\mathrm{NO}_{3}\right)_{3} \cdot 6 \mathrm{H}_{2} \mathrm{O}(8.77 \mathrm{mg}, 0.02 \mathrm{mmol})$ in $5 \mathrm{~mL}$ of dimethylformamide (DMF). The tube was sealed and allowed to stand for about two months to obtain purple block-shaped single crystals suitable for X-ray diffraction. Yield: $3.15 \mathrm{mg}(24 \%)$. The IR spectrum and the assignment of the main bands are included in the supporting information (Figure S6 and Table S1).

\subsection{Synthesis of $\left[\mathrm{Dy} y_{2}\left(\mathrm{C}_{6} \mathrm{O}_{4}(\mathrm{CN}) \mathrm{Cl}\right)_{3}(\mathrm{DMF})_{6}\right] \cdot 4 \mathrm{H}_{2} \mathrm{O}(\mathbf{2})$}

Compound 2 was obtained as single crystals by carefully layering, at room temperature, a solution of $\left[\mathrm{Ph}_{4} \mathrm{P}_{2}\left[\mathrm{C}_{6} \mathrm{O}_{4}(\mathrm{CN}) \mathrm{Cl}\right] \cdot 2 \mathrm{H}_{2} \mathrm{O}(18.25 \mathrm{mg}, 0.02 \mathrm{mmol})\right.$ in $5 \mathrm{~mL}$ of methanol, on top of a solution of Dy $\left(\mathrm{NO}_{3}\right)_{3} \cdot 5 \mathrm{H}_{2} \mathrm{O}(8.77 \mathrm{mg}, 0.02 \mathrm{mmol})$ in $5 \mathrm{~mL}$ of DMF. The tube was sealed and allowed to stand for about one month to obtain red prismatic single crystals suitable for $\mathrm{X}$-ray diffraction. Yield: $2.33 \mathrm{mg}(16 \%)$. The IR spectrum and the assignment of the main bands are included in the supporting information (Figure S7 and Table S1).

\subsection{Synthesis of $\left[\mathrm{Ho}_{2}\left(\mathrm{C}_{6} \mathrm{O}_{4}(\mathrm{CN}) \mathrm{Cl}\right)_{3}(\mathrm{DMF})_{6}\right] \cdot 2 \mathrm{H}_{2} \mathrm{O}(3)$}

Compound 3 was obtained as single crystals by carefully layering, at room temperature, a solution of $\mathrm{Ho}\left(\mathrm{NO}_{3}\right)_{3} \cdot 5 \mathrm{H}_{2} \mathrm{O}(8.82 \mathrm{mg}, 0.02 \mathrm{mmol})$ in $5 \mathrm{~mL}$ of methanol, on top of a solution of $\mathrm{KH}\left[\mathrm{C}_{6} \mathrm{O}_{4}(\mathrm{CN}) \mathrm{Cl}\right]$ $(4.75 \mathrm{mg}, 0.02 \mathrm{mmol})$ in $5 \mathrm{~mL}$ of DMF. The tube was sealed and allowed to stand for about one month to obtain red block-shaped single crystals suitable for X-ray diffraction. Yield: $1.55 \mathrm{mg}(11 \%)$. The IR spectrum and the assignment of the main bands are included in the supporting information (Figure S8 and Table S1).

\subsection{Synthesis of $\left[\mathrm{Ce}_{2}\left(\mathrm{C}_{6} \mathrm{O}_{4}(\mathrm{CN}) \mathrm{Cl}\right)_{3}(\mathrm{DMSO})_{6}\right](4)$}

Compound 4 was obtained as single crystals by carefully layering, at room temperature, a solution of $\mathrm{Ce}\left(\mathrm{NO}_{3}\right)_{3} \cdot 6 \mathrm{H}_{2} \mathrm{O}(8.68 \mathrm{mg}, 0.02 \mathrm{mmol})$ in $5 \mathrm{~mL}$ of methanol, on top of a solution of $\mathrm{KH}\left[\mathrm{C}_{6} \mathrm{O}_{4}(\mathrm{CN}) \mathrm{Cl}\right]$ ( $4.75 \mathrm{mg}, 0.02 \mathrm{mmol}$ ) in $5 \mathrm{~mL}$ of dimethylsulfoxide (DMSO). The tube was sealed and allowed to stand for about five months to obtain purple rhombohedral single crystals suitable for X-ray diffraction. Yield: $2.83 \mathrm{mg}(21 \%)$. The IR spectrum and the assignment of the main bands are included in the supporting information (Figure S9 and Table S1). 


\subsection{Synthesis of $\left[\mathrm{Nd}_{2}\left(\mathrm{C}_{6} \mathrm{O}_{4}(\mathrm{CN}) \mathrm{Cl}\right)_{3}(\mathrm{DMSO})_{6}\right]$ (5)}

Compound 5 was obtained as single crystals by carefully layering, at room temperature, a solution of $\mathrm{Nd}\left(\mathrm{NO}_{3}\right)_{3} \cdot 6 \mathrm{H}_{2} \mathrm{O}(8.77 \mathrm{mg}, 0.02 \mathrm{mmol})$ in $5 \mathrm{~mL}$ of methanol, on top of a solution of $\mathrm{KH}\left[\mathrm{C}_{6} \mathrm{O}_{4}(\mathrm{CN}) \mathrm{Cl}\right]$ $(4.75 \mathrm{mg}, 0.02 \mathrm{mmol}$ ) in $5 \mathrm{~mL}$ of DMSO. The tube was sealed and allowed to stand for about one month to obtain orange block-shaped single crystals suitable for X-ray diffraction. Yield: $5.50 \mathrm{mg}(41 \%)$. The IR spectrum and the assignment of the main bands are included in the supporting information (Figure S10 and Table S1).

\subsection{Magnetic Measurements}

Magnetic susceptibility measurements were carried out in the temperature range 2-300 K with an applied magnetic field of $0.5 \mathrm{~T}$ on polycrystalline samples of compounds 1-5 with a Quantum Design MPMS-XL-5 SQUID susceptometer (San Diego, CA, USA). The susceptibility data were corrected for the sample holders previously measured using the same conditions and for the diamagnetic contributions of the salt as deduced by using Pascal's constant tables [48].

\subsection{Crystallographic Data Collection and Refinement}

Suitable single crystals of compounds 1-5 were manually mounted in a loop using a viscous hydrocarbon oil and transferred directly to the cold nitrogen stream for data collection. Since compounds 2 and 3 show a very fast loss of crystallinity, single crystals of these compounds were extracted from their solutions immediately before their use. X-ray data were collected at $120 \mathrm{~K}$ on a Supernova diffractometer equipped with a graphite monochromated Enhance (Mo) X-ray Source $(\lambda=0.71073 \AA)$. Unit cell determinations and data reduction was performed with the program CrysAlisPro, Oxford Diffraction Ltd. [49]. Empirical absorption correction was performed using spherical harmonics, implemented in the SCALE3 ABSPACK scaling algorithm. Compounds 1, 4 and 5 crystallize in the monoclinic $P 2_{1} / n$ space group and compounds 2 and 3 in the monoclinic $\mathrm{C} 2 / \mathrm{c}$ space group (Table 1 ). Crystal structures were solved and refined against all $\mathrm{F}^{2}$ values with the SHELXL-2014 program [50], using the WinGX2014.1 graphical user interface [51]. Non-hydrogen atoms were refined anisotropically and hydrogen atoms were assigned fixed isotropic displacement parameters. Hydrogen atoms associated with oxygen atoms were located from the difference map and the O-H distance fixed at $0.86 \AA$. Table 1 displays a summary of the data collection and structure refinements for compounds $\mathbf{1 - 5 .}$

CCDC-1877130-4 contain the supplementary crystallographic data for compounds 1-5, respectively. These data can be obtained free of charge from The Cambridge Crystallographic Data Centre at www.ccdc.cam.ac.uk/data_request/cif.

\subsection{X-ray Powder Diffraction}

The X-ray powder diffractograms were collected for of all compounds (using the same polycrystalline samples used for the magnetic measurements) with a $0.5 \mathrm{~mm}$ glass capillary that was mounted and aligned on a Empyrean PANalytical powder diffractometer, using CuK $\alpha$ radiation $(\lambda=1.54177 \AA)$. A total of 3 or 6 scans were collected at room temperature in the $2 \theta$ range $2-40^{\circ}$. The partial loss of crystallinity of samples $\mathbf{2}$ and $\mathbf{3}$ is attributed to the loss of solvent molecules during the storage and magnetic measurements.

\subsection{IR Spectroscopy}

FT-IR spectra were performed on $\mathrm{KBr}$ pellets and collected with a Nexus-Nicolet 5700 spectrophotometer in the range $400-4000 \mathrm{~cm}^{-1}$. 


\section{Conclusions}

The combination of different $\operatorname{Ln}(\mathrm{III})$ ions as Nd, Dy, Ho and Ce with the asymmetric anilato derivative ligand chlorocyananilato and using DMF and DMSO as coordinating solvents, have led to the formation of five new compounds formulated as: $\left[\mathrm{Nd}_{2}\left(\mathrm{C}_{6} \mathrm{O}_{4}(\mathrm{CN}) \mathrm{Cl}\right)_{3}(\mathrm{DMF})_{6}\right](\mathbf{1})$, $\left[\mathrm{Dy}_{2}\left(\mathrm{C}_{6} \mathrm{O}_{4}(\mathrm{CN}) \mathrm{Cl}\right)_{3}(\mathrm{DMF})_{6}\right] \cdot 4 \mathrm{H}_{2} \mathrm{O}(2),\left[\mathrm{Ho}_{2}\left(\mathrm{C}_{6} \mathrm{O}_{4}(\mathrm{CN}) \mathrm{Cl}\right)_{3}(\mathrm{DMF})_{6}\right] \cdot 2 \mathrm{H}_{2} \mathrm{O}(3)$ and $\left[\operatorname{Ln}_{2}\left(\mathrm{C}_{6} \mathrm{O}_{4}(\mathrm{CN}) \mathrm{Cl}\right)\right.$ ${ }_{3}(\mathrm{DMSO})_{6}$ ] with $\mathrm{Ln}=\mathrm{Ce}(4)$ and $\mathrm{Nd}(5)$. All compounds show honeycomb (6,3)-2D lattices with quite regular hexagonal cavities in the compounds with small ions (Dy in 2 and Ho in 3) and rectangular cavities in the compounds with large cations ( $\mathrm{Nd}$ in $\mathbf{1}$ and $\mathbf{5}$ and Ce in $\mathbf{4}$ ). A detailed analysis of the coordination geometry and of the positions occupied by the anilato ligands and the solvent molecules leads to the conclusion that the spatial disposition of the ligands around the $\mathrm{Ln}(\mathrm{III})$ ion determines the shape and distortion of the cavities, since in all compounds the coordination geometry is the same (capped square anti-prism). This aspect is important since the hexagonal cavities contain additional water crystallization molecules but the rectangular ones do not have enough free space to accommodate any water molecules.

The synthesis of the complete $\operatorname{Ln}(\mathrm{III})$ series with this ligand and these and other solvents is under investigation in order to elucidate the role played by the size and shape of the solvent and by the size of the $\mathrm{Ln}(\mathrm{III})$ ions in their final structures and properties. The luminescent properties of these compounds are also under study since both, the $\operatorname{Ln}(\mathrm{III})$ ions and the asymmetric ligand chlorocyananilato, are good candidates to show luminescence.

Supplementary Materials: The following are available online at http://www.mdpi.com/2312-7481/ 4/4/58/s1, Figure S1: Experimental and simulated X-ray powder diffractograms for compound $\left[\mathrm{Nd}_{2}\left(\mathrm{C}_{6} \mathrm{O}_{4}(\mathrm{CN}) \mathrm{Cl}\right)_{3}(\mathrm{DMF})_{6}\right](\mathbf{1})$, Figure S2: Experimental and simulated X-ray powder diffractograms for compound $\left[\mathrm{Dy}_{2}\left(\mathrm{C}_{6} \mathrm{O}_{4}(\mathrm{CN}) \mathrm{Cl}\right)_{3}(\mathrm{DMF})_{6}\right] \cdot 4 \mathrm{H}_{2} \mathrm{O}(2)$, Figure S3: Experimental and simulated X-ray powder diffractograms for compound $\left[\mathrm{Ho}_{2}\left(\mathrm{C}_{6} \mathrm{O}_{4}(\mathrm{CN}) \mathrm{Cl}\right)_{3}(\mathrm{DMF})_{6}\right] \cdot 2 \mathrm{H}_{2} \mathrm{O}$ (3), Figure S4: Experimental and simulated X-ray powder diffractograms for compound $\left[\mathrm{Ce}_{2}\left(\mathrm{C}_{6} \mathrm{O}_{4}(\mathrm{CN}) \mathrm{Cl}\right)_{3}(\mathrm{DMSO})_{6}\right](4)$, Figure S5: Experimental and simulated X-ray powder diffractograms for compound $\left[\mathrm{Nd}_{2}\left(\mathrm{C}_{6} \mathrm{O}_{4}(\mathrm{CN}) \mathrm{Cl}\right)_{3}(\mathrm{DMSO})_{6}\right]$ (5), Figure S6: IR spectrum of compound $\left[\mathrm{Nd}_{2}\left(\mathrm{C}_{6} \mathrm{O}_{4}(\mathrm{CN}) \mathrm{Cl}\right)_{3}(\mathrm{DMF})_{6}\right]$ (1) in (a) the $4000-400 \mathrm{~cm}^{-1}$ and (b) $2000-400 \mathrm{~cm}^{-1}$ ranges, Figure S7: IR spectrum of compound $\left[\mathrm{Dy}_{2}\left(\mathrm{C}_{6} \mathrm{O}_{4}(\mathrm{CN}) \mathrm{Cl}\right)_{3}(\mathrm{DMF})_{6}\right] \cdot 4 \mathrm{H}_{2} \mathrm{O}(2)$ in (a) the $4000-400 \mathrm{~cm}^{-1}$ and (b) $2000-400 \mathrm{~cm}^{-1}$ ranges, Figure S8: IR spectrum of compound $\left[\mathrm{Ho}_{2}\left(\mathrm{C}_{6} \mathrm{O}_{4}(\mathrm{CN}) \mathrm{Cl}\right)_{3}(\mathrm{DMF})_{6}\right] \cdot 2 \mathrm{H}_{2} \mathrm{O}(3)$ in (a) the $4000-400 \mathrm{~cm}^{-1}$ and (b) 2000-400 $\mathrm{cm}^{-1}$ ranges, Figure S9; IR spectrum of compound $\left[\mathrm{Ce}_{2}\left(\mathrm{C}_{6} \mathrm{O}_{4}(\mathrm{CN}) \mathrm{Cl}\right)_{3}(\mathrm{DMSO})_{6}\right]$ (4) in (a) the $4000-400 \mathrm{~cm}^{-1}$ and (b) 2000-400 $\mathrm{cm}^{-1}$ ranges, Figure S10: IR spectrum of compound $\left[\mathrm{Nd}_{2}\left(\mathrm{C}_{6} \mathrm{O}_{4}(\mathrm{CN}) \mathrm{Cl}\right)_{3}(\mathrm{DMSO})_{6}\right]$ (5) in (a) the $4000-400 \mathrm{~cm}^{-1}$ and (b) 2000-400 $\mathrm{cm}^{-1}$ ranges, Table S1: Main IR bands $\left(\mathrm{cm}^{-1}\right)$ and their assignment in compounds $\left[\mathrm{Nd}_{2}\left(\mathrm{C}_{6} \mathrm{O}_{4}(\mathrm{CN}) \mathrm{Cl}\right)_{3}(\mathrm{DMF})_{6}\right](\mathbf{1})\left[\mathrm{Dy}_{2}\left(\mathrm{C}_{6} \mathrm{O}_{4}(\mathrm{CN}) \mathrm{Cl}\right)_{3}(\mathrm{DMF})_{6}\right] \cdot 4 \mathrm{H}_{2} \mathrm{O}$ (2), $\left[\mathrm{Ho}_{2}\left(\mathrm{C}_{6} \mathrm{O}_{4}(\mathrm{CN}) \mathrm{Cl}\right)_{3}(\mathrm{DMF})_{6}\right] \cdot 2 \mathrm{H}_{2} \mathrm{O}(3)$, and $\left[\mathrm{Ln}_{2}\left(\mathrm{C}_{6} \mathrm{O}_{4}(\mathrm{CN}) \mathrm{Cl}\right)_{3}(\mathrm{DMSO})_{6}\right]$ with $\mathrm{Ln}=\mathrm{Ce}(4)$ and $\mathrm{Nd}(5)$.

Author Contributions: S.B. designed the synthesis, performed the $\mathrm{X}$-ray structural analysis and supervised all the experiments. A.H.-P. performed the synthesis of the ligand and of the compounds. C.J.G.-G. performed the magnetic measurements and supervised all the experiments. All the authors contributed to the writing of the manuscript.

Funding: This research was funded by the Generalitat Valenciana (Prometeo2014/II/076 project) and the Spanish MINECO (Project CTQ2017-87201-P AEI/FEDER, EU).

Acknowledgments: A.H.-P. thanks the Spanish MINECO for a pre-doctoral grant (FPU Program).

Conflicts of Interest: The authors declare no conflict of interest.

\section{References}

1. Zhou, H.C.; Long, J.R.; Yaghi, O.M. Introduction to metal-organic frameworks. Chem. Rev. 2012, 112, 673-674. [CrossRef] [PubMed]

2. Furukawa, H.; Cordova, K.E.; O'Keeffe, M.; Yaghi, O.M. The chemistry and applications of metal-organic frameworks. Science 2013, 341, 1230444. [CrossRef] [PubMed]

3. Nandasiri, M.I.; Jambovane, S.R.; McGrail, B.P.; Schaef, H.T.; Nune, S.K. Adsorption, separation, and catalytic properties of densified metal-organic frameworks. Coord. Chem. Rev. 2016, 311, 38-52. [CrossRef]

4. Huang, Y.B.; Liang, J.; Wang, X.S.; Cao, R. Multifunctional metal-organic framework catalysts: Synergistic catalysis and tandem reactions. Chem. Soc. Rev. 2017, 46, 126-157. [CrossRef] [PubMed] 
5. Barea, E.; Montoro, C.; Navarro, J.A. Toxic gas removal-Metal-organic frameworks for the capture and degradation of toxic gases and vapours. Chem. Soc. Rev. 2014, 43, 5419-5430. [CrossRef] [PubMed]

6. Schoedel, A.; Ji, Z.; Yaghi, O.M. The role of metal-organic frameworks in a carbon-neutral energy cycle. Nat. Energy 2016, 1, 16034. [CrossRef]

7. Wang, L.; Han, Y.; Feng, X.; Zhou, J.; Qi, P.; Wang, B. Metal-organic frameworks for energy storage: Batteries and supercapacitors. Coord. Chem. Rev. 2016, 307, 361-381. [CrossRef]

8. Bai, S.; Liu, X.; Zhu, K.; Wu, S.; Zhou, H. Metal-organic framework-based separator for lithium-sulfur batteries. Nat. Energy 2016, 1, 16094. [CrossRef]

9. Canivet, J.; Fateeva, A.; Guo, Y.; Coasne, B.; Farrusseng, D. Water adsorption in MOFs: Fundamentals and applications. Chem. Soc. Rev. 2014, 43, 5594-5617. [CrossRef]

10. Horcajada, P.; Gref, R.; Baati, T.; Allan, P.K.; Maurin, G.; Couvreur, P.; Ferey, G.; Morris, R.E.; Serre, C. Metal-organic frameworks in biomedicine. Chem. Rev. 2012, 112, 1232-1268. [CrossRef]

11. Wu, M.X.; Yang, Y.W. Metal-Organic Framework (MOF)-Based Drug/Cargo Delivery and Cancer Therapy. Adv. Mater. 2017, 29, 1606134. [CrossRef] [PubMed]

12. Kreno, L.E.; Leong, K.; Farha, O.K.; Allendorf, M.; Van Duyne, R.P.; Hupp, J.T. Metal-organic framework materials as chemical sensors. Chem. Rev. 2012, 112, 1105-1125. [CrossRef] [PubMed]

13. Campbell, M.G.; Dinca, M. Metal-Organic Frameworks as Active Materials in Electronic Sensor Devices. Sensors 2017, 17, 1108. [CrossRef] [PubMed]

14. Li, B.; Wen, H.M.; Cui, Y.; Zhou, W.; Qian, G.; Chen, B. Emerging Multifunctional Metal-Organic Framework Materials. Adv. Mater. 2016, 28, 8819-8860. [CrossRef] [PubMed]

15. Fordham, S.; Wang, X.; Bosch, M.; Zhou, H. Lanthanide Metal-Organic Frameworks: Syntheses, Properties, and Potential Applications. Struct. Bond. 2015, 163, 1-27.

16. Wang, C.; Liu, X.; Keser Demir, N.; Chen, J.P.; Li, K. Applications of water stable metal-organic frameworks. Chem. Soc. Rev. 2016, 45, 5107-5134. [CrossRef] [PubMed]

17. Liu, X.; Fu, W.; Bouwman, E. One-step growth of lanthanoid metal-organic framework (MOF) films under solvothermal conditions for temperature sensing. Chem. Commun. 2016, 52, 6926-6929. [CrossRef] [PubMed]

18. Zhang, W.; Zhang, W.; Wang, R.; Ren, C.; Li, Q.; Fan, Y.; Liu, B.; Liu, P.; Wang, Y. Effect of Coordinated Solvent Molecules on Metal Coordination Sphere and Solvent-Induced Transformations. Cryst. Growth Des. 2017, 17, 517-526. [CrossRef]

19. Li, X.; Sun, X.; Li, X.; Fu, Z.; Su, Y.; Xu, G. Porous Cadmium(II) Anionic Metal-Organic Frameworks Based on Aromatic Tricarboxylate Ligands: Encapsulation of Protonated Flexible Bis(2-methylimidazolyl) Ligands and Proton Conductivity. Cryst. Growth Des. 2015, 15, 4543-4548. [CrossRef]

20. Sun, L.; Qi, Y.; Che, Y.; Batten, S.R.; Zheng, J. Three Unprecedented Entangled Metal-Organic Frameworks: Self-Penetration and Hydrothermal in Situ Ligand Formation. Cryst. Growth Des. 2009, 9, 2995-2998. [CrossRef]

21. Zhao, D.; Timmons, D.J.; Yuan, D.; Zhou, H.C. Tuning the topology and functionality of metal-organic frameworks by ligand design. Acc. Chem. Res. 2011, 44, 123-133. [CrossRef] [PubMed]

22. Banerjee, R.; Phan, A.; Wang, B.; Knobler, C.; Furukawa, H. High-Throughput Synthesis of Zeolitic Imidazolate Frameworks and Application to $\mathrm{CO}_{2}$ Capture. Science 2008, 319, 939-943. [CrossRef] [PubMed]

23. Zhang, J.P.; Zhang, Y.B.; Lin, J.B.; Chen, X.M. Metal azolate frameworks: From crystal engineering to functional materials. Chem. Rev. 2012, 112, 1001-1033. [CrossRef] [PubMed]

24. Kitagawa, S.; Kawata, S. Coordination compounds of 1,4-dihydroxybenzoquinone and its homologues. Structures and properties. Coord. Chem. Rev. 2002, 224, 11-34. [CrossRef]

25. Mercuri, M.L.; Congiu, F.; Concas, G.; Sahadevan, S.A. Recent Advances on Anilato-Based Molecular Materials with Magnetic and/or Conducting Properties. Magnetochemistry 2017, 3, 17. [CrossRef]

26. Atzori, M.; Artizzu, F.; Sessini, E.; Marchio, L.; Loche, D.; Serpe, A.; Deplano, P.; Concas, G.; Pop, F.; Avarvari, N.; et al. Halogen-bonding in a new family of tris(haloanilato)metallate(III) magnetic molecular building blocks. Dalton Trans. 2014, 43, 7006-7019. [CrossRef] [PubMed]

27. Benmansour, S.; Gómez-Claramunt, P.; Vallés-García, C.; Mínguez Espallargas, G.; Gómez García, C.J. Key Role of the Cation in the Crystallization of Chiral Tris(Anilato)Metalate Magnetic Anions. Cryst. Growth Des. 2016, 16, 518-526. [CrossRef]

28. Abrahams, B.F.; Coleiro, J.; Ha, K.; Hoskins, B.F.; Orchard, S.D.; Robson, R. Dihydroxybenzoquinone and chloranilic acid derivatives of rare earth metals. J. Chem. Soc. Dalton Trans. 2002, 8, 1586-1594. [CrossRef] 
29. Abrahams, B.F.; Hudson, T.A.; McCormick, L.J.; Robson, R. Coordination polymers of 2,5-dihydroxybenzoquinone and chloranilic acid with the (10,3)-a Topology. Cryst. Growth Des. 2011, 11, 2717-2720. [CrossRef]

30. Atzori, M.; Benmansour, S.; Mínguez Espallargas, G.; Clemente-León, M.; Abhervé, A.; Gómez-Claramunt, P.; Coronado, E.; Artizzu, F.; Sessini, E.; Deplano, P.; et al. A Family of Layered Chiral Porous Magnets Exhibiting Tunable Ordering Temperatures. Inorg. Chem. 2013, 52, 10031-10040. [CrossRef] [PubMed]

31. Benmansour, S.; Vallés-García, C.; Gómez-Claramunt, P.; Mínguez Espallargas, G.; Gómez-García, C.J. 2D and 3D Anilato-Based Heterometallic M(I)M(III) Lattices: The Missing Link. Inorg. Chem. 2015, 54, 5410-5418. [CrossRef] [PubMed]

32. Benmansour, S.; Gómez-García, C.J. A Heterobimetallic Anionic 3,6-Connected 2D Coordination Polymer Based on Nitranilate as Ligand. Polymers 2016, 8, 89. [CrossRef]

33. Benmansour, S.; Abhervé, A.; Gómez-Claramunt, P.; Vallés-García, C.; Gómez-García, C.J. Nanosheets of Two-Dimensional Magnetic and Conducting Fe(II)/Fe(III) Mixed-Valence Metal-Organic Frameworks. ACS Appl. Mater. Interfaces 2017, 9, 26210-26218. [CrossRef] [PubMed]

34. Jeon, I.; Negru, B.; Duyne, R.P.V.; Harris, T.D. A 2D Semiquinone Radical-Containing Microporous Magnet with Solvent-Induced Switching from $\mathrm{T}_{\mathrm{C}}=26$ to $80 \mathrm{~K}$. J. Am. Chem. Soc. 2015, 137, 15699-15702. [CrossRef] [PubMed]

35. Abrahams, B.F.; Coleiro, J.; Hoskins, B.F.; Robson, R. Gas hydrate-like pentagonal dodecahedral $\mathrm{M}_{2}\left(\mathrm{H}_{2} \mathrm{O}\right)_{18}$ cages $(\mathrm{M}=$ lanthanide or $\mathrm{Y})$ in 2,5-dihydroxybenzoquinone-derived coordination polymers. Chem. Commun. 1996, 603-604. [CrossRef]

36. López-Martínez, G. Multifunctionality in Molecular Materials Based on Anilato-Type Ligands. Ph.D. Thesis, University of Valencia, València, Spain, 2017.

37. Benmansour, S.; Pérez-Herráez, I.; López-Martínez, G.; Gómez García, C.J. Solvent-modulated structures in anilato-based 2D coordination polymers. Polyhedron 2017, 135, 17-25. [CrossRef]

38. Benmansour, S.; López-Martínez, G.; Canet-Ferrer, J.; Gómez-García, C.J. A Family of Lanthanoid Dimers with Nitroanilato Bridges. Magnetochemistry 2016, 2, 3. [CrossRef]

39. Gómez-Claramunt, P.; Benmansour, S.; Hernández-Paredes, A.; Cerezo-Navarrete, C.; Rodríguez-Fernández, C.; Canet-Ferrer, J.; Cantarero, A.; Gómez-García, C.J. Tuning the Structure and Properties of Lanthanoid Coordination Polymers with an Asymmetric Anilato Ligand. Magnetochemistry 2018, 4, 6. [CrossRef]

40. Riley, P.E.; Haddad, S.F.; Raymond, K.N. Preparation of praseodymium(III) chloranilate and the crystal structures of $\mathrm{Pr}_{2}\left(\mathrm{C}_{6} \mathrm{Cl}_{2} \mathrm{O}_{4}\right)_{3} \cdot 8 \mathrm{C}_{2} \mathrm{H}_{5} \mathrm{OH}$ and $\mathrm{Na}_{3}\left[\mathrm{C}_{6} \mathrm{H}_{2} \mathrm{O}(\mathrm{OH})\left(\mathrm{SO}_{3}\right)_{2}\right] \cdot \mathrm{H}_{2} \mathrm{O}$. Inorg. Chem. 1983, 22, 3090-3096.

41. Diaz-Torres, R.; Alvarez, S. Coordinating ability of anions and solvents towards transition metals and lanthanides. Dalton Trans. 2011, 40, 10742-10750. [CrossRef]

42. Benmansour, S.; Pérez-Herráez, I.; Cerezo-Navarrete, C.; López-Martínez, G.; Martínez Hernandez, C.; Gómez-García, C.J. Solvent-modulation of the structure and dimensionality in lanthanoid-anilato coordination polymers. Dalton Trans. 2018, 47, 6729-6741. [CrossRef] [PubMed]

43. Benmansour, S.; Hernández-Paredes, A.; Gómez-García, C.J. Effect of the lanthanoid-size on the structure of a series of lanthanoid-anilato 2-D lattices. J. Coord. Chem. 2018, 71, 845-863. [CrossRef]

44. Llunell, M.; Casanova, D.; Cirera, J.; Bofill, J.M.; Alemany, P.; Alvarez, S.; Pinsky, M.; Avnir, D. SHAPE, version 2.3; University of Barcelona: Barcelona, Spain, 2013.

45. Ruiz-Martínez, A.; Casanova, D.; Alvarez, S. Polyhedral Structures with an Odd Number of Vertices: Nine-Coordinate Metal Compounds. Chem. Eur. J. 2008, 14, 1291-1303. [CrossRef]

46. Sorace, L.; Gatteschi, D. Electronic Structure and Magnetic Properties of Lanthanide Molecular Complexes; Layfield, R.A., Murugesu, M., Eds.; Wiley-VCH: Weinheim, Germany, 2015; Volume 1, pp. 1-25.

47. Atzori, M.; Artizzu, F.; Marchio, L.; Loche, D.; Caneschi, A.; Serpe, A.; Delano, P.; Avarvari, N.; Mercuri, M.L. Switching-on luminescence in anilate-based molecular materials. Dalton Trans. 2015, 44, 15786-15802. [CrossRef] [PubMed]

48. Bain, G.A.; Berry, J.F. Diamagnetic corrections and Pascal's constants. J. Chem. Educ. 2008, 85, 532-536. [CrossRef]

49. CrysAlisPro, Version 171.33.55; Oxford Diffraction Ltd.: Oxford, UK, 2004.

50. Sheldrick, G.M. Crystal structure refinement with SHELXL. Acta Cryst. C 2015, 71, 3-8. [CrossRef] [PubMed]

51. Farrugia, L.J. WinGX and ORTEP for Windows: An update. J. Appl. Cryst. 2012, 45, 849-854. [CrossRef]

(C) 2018 by the authors. Licensee MDPI, Basel, Switzerland. This article is an open access article distributed under the terms and conditions of the Creative Commons Attribution (CC BY) license (http:/ / creativecommons.org/licenses/by/4.0/). 